\title{
In situ quantification of the nitrogen content of olivine-hosted melt inclusions from Klyuchevskoy volcano (Kamchatka): Implications for nitrogen recycling at subduction zones
}

\author{
Evelyn Füri ${ }^{\mathrm{a},{ }^{*}}$, Maxim Portnyagin ${ }^{\mathrm{b}, \mathrm{c}}$, Nikita Mironov ${ }^{\mathrm{c}}$, \\ Cécile Deligny ${ }^{\mathrm{a}}$, Andrey Gurenko ${ }^{\mathrm{a}}$, Roman Botcharnikov ${ }^{\mathrm{d}}$, François Holtz ${ }^{\mathrm{e}}$
}

${ }^{a}$ Université de Lorraine, CNRS, CRPG, F-54000 Nancy, France

${ }^{\mathrm{b}}$ GEOMAR Helmholtz Centre for Ocean Research Kiel, Wischhofstr. 1-3, 24148 Kiel, Germany

${ }^{\text {c }}$ V.I. Vernadsky Institute of Geochemistry and Analytical Chemistry, Kosygin 19, 119991, Moscow, Russia

${ }^{\mathrm{d}}$ Institut für Geowissenschaften, Johannes Gutenberg Universität Mainz, J.-J.-Becher-Weg 21, 55128 Mainz, Germany

${ }^{\mathrm{e}}$ Leibniz Universität Hannover, Institut für Mineralogie, Callinstr. 3, 30167 Hannover, Germany

* Corresponding author e-mail address: efueri@crpg.cnrs-nancy.fr

This is a pre-print of an article published in Chemical Geology. The final authenticated version is available online at: https://www.sciencedirect.com/science/article/abs/pii/S0009254121003995

\begin{abstract}
Assessing the $\mathrm{N}$ content of arc magmas and their mantle source remains a challenge because the volatile element composition of melts and gases can be modified during magma ascent, storage, and eruption. Given that melt inclusions (MIs) in Mg-rich olivine represent the best proxies for primary arc melts, we applied, for the first time, an in situ high-resolution secondary ion mass spectrometry (SIMS) method to determine the $\mathrm{N}$ concentration in olivine-hosted MIs from Klyuchevskoy volcano in Kamchatka. To reverse the effects of post-entrapment modification processes (i.e., exsolution of volatiles into a fluid bubble), the MIs were partially to completely homogenized at high temperatures $\left(1150-1400^{\circ} \mathrm{C}\right)$ and pressures ranging from 0.1 to $500 \mathrm{MPa}$ under dry to $\mathrm{H}_{2} \mathrm{O}$-saturated conditions at variable oxygen fugacities ( $\mathrm{CCO}$ to $\mathrm{QFM}+3.3)$. After the experiments, $\mathrm{N}$ concentrations in water-rich MI glasses correlate positively with $\mathrm{H}_{2} \mathrm{O}$ and $\mathrm{CO}_{2}$ contents as well as with $\mathrm{N} / \mathrm{CO}_{2}$ ratios, and negatively with the volume of the remaining fluid bubble. Glasses of completely homogenized (fluid bubble-free) MIs contain up to $25.7 \pm 0.5 \mathrm{ppm} \mathrm{N}$, whereas glasses of three unheated (natural, bubblebearing) MIs have significantly lower $\mathrm{N}$ concentrations of $\sim 1 \pm 0.3 \mathrm{ppm}$. The $\mathrm{N}-\mathrm{CO}_{2}-\mathrm{Nb}$ characteristics of completely homogenized MIs indicate that melts feeding Klyuchevskoy volcano have high absolute concentrations of both $\mathrm{N}$ and $\mathrm{CO}_{2}$, as well as large excess of these volatiles relative to $\mathrm{Nb}$, compared to primary mid-ocean ridge melts. This implies that large amounts of $\mathrm{N}$ and $\mathrm{CO}_{2}$ in Klyuchevskoy melts and their mantle source are derived from the subducting slab, and that these subducted volatiles are (partially) returned to the crust and atmosphere by arc-related magmatism.
\end{abstract}

Keywords: Nitrogen, SIMS, melt inclusions, subduction, volatile recycling, Klyuchevskoy volcano 


\section{Introduction}

A quantitative understanding of nitrogen fluxes and pre-eruptive magmatic concentrations in subduction zones is key for constraining the $\mathrm{N}$ recycling efficiency between Earth's internal and external reservoirs. Biological uptake of $\mathrm{N}$ from the atmosphere/hydrosphere, followed by the gradual transfer of $\mathrm{N}$ - in organic matter or as lattice-bound ammonium $\left(\mathrm{NH}_{4}{ }^{+}\right)$in potassium-bearing minerals within seafloor sediments and altered oceanic crust - to sub-arc depths and beyond, depletes the surficial N reservoir (e.g., Zerkle and Mikhail, 2017), whereas mantle degassing (at volcanic arcs, mid-ocean-ridges, and oceanic islands) releases molecular $\mathrm{N}_{2}$ from Earth's interior to the atmosphere (Sano et al., 2001). However, the fate of $\mathrm{N}$ at convergent plate margins is still debated because various factors, such as the pressure-temperature path, lithologies, and structure of the subducting slab as well as the oxygen fugacity (Jackson et al., 2021; Lee et al., 2017; Li and Keppler, 2014; Mallik et al., 2018; Mikhail et al., 2017; Mysen, 2019), influence the efficiency with which subducted $\mathrm{N}$ is returned to Earth's surface via arc volcanism or entrained into the mantle beyond the zone of arc magma generation (e.g., Bebout et al., 2016; Bebout and Fogel, 1992; Busigny et al., 2019, 2003; Halama et al., 2012, 2010; Li et al., 2007; Li and Bebout, 2005; Mallik et al., 2018; Mitchell et al., 2010; Zimmer et al., 2004). As a consequence, different estimates of degassed versus subducted $\mathrm{N}$ in arc settings range from near complete fore-arc or sub-arc slab devolatilization (e.g., Elkins et al., 2006; Fischer et al., 2002; Hilton et al., 2002; Snyder et al., 2003) to up to $80-92 \%$ transport of $\mathrm{N}$ beyond sub-arc depths into the (deep) mantle (Barry and Hilton, 2016; Busigny et al., 2011).

Most previous studies of the $\mathrm{N}$ source(s) and degassing flux at convergent margins relied on analyses of gas and/or water samples from arc volcanoes and associated hydrothermal systems (e.g., (Clor et al., 2005; Elkins et al., 2006; Fischer et al., 2015, 2002; Halldórsson et al., 2013; Lee et al., 2017; Mitchell et al., 2010; Sano et al., 2001, 1998; Taran, 2009; Zimmer et al., 2004). A major concern for identifying and quantifying various contributory sources for the volcanic $\mathrm{N}$ output is that the $\mathrm{N}$ abundance and isotope ratio of these samples may have been affected by the addition of an atmospheric component (either air or air-saturated water) prior to or during sampling (e.g., Hilton et al., 2002). Although the three-component model of Sano et al. (2001), for example, provides a means to resolve the provenance of $\mathrm{N}$, i.e., to estimate the relative contributions from air, sediments, and the mantle to the total $\mathrm{N}$ content, this approach requires knowledge of the isotopic composition $\left({ }^{15} \mathrm{~N} /{ }^{14} \mathrm{~N}\right.$ ratio) and elemental abundance ratios (e.g, $\mathrm{N}_{2} / \mathrm{Ar}$ ) of the endmembers. Furthermore, it relies on the assumptions that there is no additional $\mathrm{N}$ input from the arc crust, and that isotopic and elemental ratios in the volcanic products are representative of the $\mathrm{N}$ source. Nitrogen is assumed to predominantly exist as $\mathrm{N}_{2}$ in arc melts and fluids (Li and Keppler, 2014; Mikhail et al., 2017; Mikhail and Sverjensky, 2015; Mysen, 2019) because of the relatively oxidizing conditions of the mantle wedge beneath arc systems (i.e., $\log f \mathrm{O}_{2}=$ QFM 0 to +2 , where QFM refers to the quartz-fayalitemagnetite solid oxygen buffer; e.g., Parkinson and Arculus, 1999). Since $\mathrm{N}_{2}$ solubility in silicate melts has been shown to be comparable to that of argon (Boulliung et al., 2020; Bernadou et al., 2021; 
Cartigny et al., 2001; Gaillard et al., 2021; Libourel et al., 2003), magmatic degassing is expected to result in limited fractionation of the $\mathrm{N}_{2} / \mathrm{Ar}$ elemental ratio. Degassing-induced changes of the $\mathrm{N}$ isotope ratio are also usually considered to be negligible (e.g. Cartigny et al., 2001; Fischer et al., 2005). However, Li et al. (2009) experimentally demonstrated that ${ }^{15} \mathrm{~N}$-depleted $\mathrm{N}_{2}$ can be generated by the partial thermal decomposition of $\mathrm{NH}_{3}$. This process can modify the isotope ratio of the 'sedimentary' N component during slab devolatilization. Thus, these findings imply that the isotopic composition of volcanic $\mathrm{N}$ may not be representative of its source signature in all cases.

To circumvent the issues of atmospheric and shallow crustal contamination, the $\mathrm{N}$ characteristics of primary undegassed arc magmas may be investigated through analyses of melt inclusions (MIs) trapped in phenocrysts of volcanic rocks. These inclusions, which are small pockets of silicate melt entrapped during crystal growth, provide direct insight into pre-eruptive concentrations and isotope ratios of $\mathrm{N}$ (and other volatiles) in the parent melt (Wallace, 2005). Fischer et al. (2005) reported the first $\mathrm{N}$ isotope data for olivine separates from subduction zones, determined by in-vacuo crushing and static mass spectrometry analysis. This method is commonly used to extract and analyze noble gases from melt and/or fluid inclusions in mineral grains (e.g., Hilton et al., 2002), and it yields precise isotope ratios for arc magmas and their mantle source; nonetheless, since the proportion of 'melt' (i.e., the number and volume of MIs) in mineral separates is usually unknown, it allows determining $\mathrm{N}$ concentrations "per gram of olivine" only, and it does not provide a quantitative estimate of the $\mathrm{N}$ content of the trapped melt. Nitrogen concentrations in individual MIs can only be determined by in situ secondary ion mass spectrometry (SIMS) (Füri et al., 2018; Regier et al., 2016). Although the $\mathrm{N}$ content of terrestrial MIs is too low to obtain ${ }^{15} \mathrm{~N} /{ }^{14} \mathrm{~N}$ ratios by this method, it permits to couple $\mathrm{N}$ analyses with measurements of other volatiles (e.g., $\mathrm{H}_{2} \mathrm{O}, \mathrm{CO}_{2}$ ) and/or major and trace elements (e.g., $\mathrm{Nb}$ ). In this way, the $\mathrm{N} / \mathrm{CO}_{2}$ and $\mathrm{N} / \mathrm{Nb}$ ratios of primary mantle melts can be assessed. However, given that SIMS measurements are carried out in the (residual) glass phase, post-entrapment modification processes in the MIs (e.g., crystallization, diffusive volatile loss through the host crystal, and/or bubble nucleation during cooling and decompression; e.g., Danyushevsky et al., 2002; Roedder, 1979; Schiano, 2003; Wallace, 2005) must be taken into account or reversed (e.g., by experimental homogenization at high temperature) to determine the volatile budget of the melt that was trapped in the host mineral prior to decompression (Mironov et al., 2015; Moore et al., 2015). This is of particular importance for $\mathrm{CO}_{2}$ and $\mathrm{N}$ because the formation of a fluid bubble can substantially deplete the coexisting melt in dissolved $\mathrm{CO}_{2}$ and $\mathrm{N}$ due to their low solubilities in silicate melt (e.g., Boulliung et al., 2020; Dixon, 1997; Dixon et al., 1995; Libourel et al., 2003; Moore et al., 2015; Wallace, 2005). Therefore, the $\mathrm{CO}_{2}$ and $\mathrm{N}$ contents measured in the glass phase of bubblebearing inclusions only provide minimum estimates of the volatile content of the parent melt. The volatile concentration in homogenized inclusions, in contrast, is expected to closely reflect that of the undegassed melt. 
The goal of this study was to determine the pre-eruptive $\mathrm{N}$ content of primitive mafic melts from Klyuchevskoy volcano based on in situ analyses of olivine-hosted MIs by SIMS. To this end, we targeted MIs that were homogenized by heating in a pressure vessel under $P-T-f \mathrm{O}_{2}$ conditions similar to those presumed to have existed when the MIs were trapped. The $\mathrm{H}_{2} \mathrm{O}-\mathrm{CO}_{2}$ systematics of these MIs were previously investigated by Mironov et al. (2015). The experimental treatment resulted in $\mathrm{H}^{+}$ diffusion through the olivine structure and re-hydration of the melt to its original $\mathrm{H}_{2} \mathrm{O}$ content (Portnyagin et al., 2019), as well as dissolution of $\mathrm{CO}_{2}$ and other volatiles (e.g., N) from the fluid bubble back into the melt. This approach allows us to compare the $\mathrm{N}-\mathrm{CO}_{2}-\mathrm{Nb}$ characteristics of the most primitive Klyuchevskoy melts with those of other mantle-derived melts, and, ultimately, to improve our understanding of the distribution of $\mathrm{N}$ in Earth's upper mantle.

\section{Samples and methods}

\subsection{Samples from Klyuchevskoy volcano}

Klyuchevskoy volcano, one of the largest and most active volcanoes in the world (with a summit elevation fluctuating between $\sim 4750$ and 4800 m above sea level due to frequent eruptions; e.g., Fedotov et al., 2010; Portnyagin and Ponomareva, 2012), is located on the Kamchatka Peninsula of eastern Russia where the Pacific plate is subducting beneath the Eurasian plate. It belongs to the Klyuchevskaya Group, a group of 12 volcanoes situated within the so-called Central Kamchatka Depression near the junction between the Kamchatka-Kuril and Aleutian island arcs in a complex geodynamic setting (e.g., Yogodzinski et al., 2001; Levin et al., 2002; Portnyagin et al., 2005; Portnyagin and Manea, 2008). Based on the unusually heavy oxygen isotope composition of olivine and pyroxene phenocrysts from Klyuchevskoy, Dorendorf et al. (2000) argued that the exceptional magma productivity is related to the addition of fluids derived from the subducting oceanic crust and the Hawaii-Emperor seamount chain to the mantle wedge. Furthermore, Portnyagin et al. (2005) suggested that influx of fertile Pacific mantle, resulting from the detachment of a fragment of the subducting slab, leads to enhanced melt production beneath Klyuchevskoy. Indeed, the 3-D seismic velocity structure of the mantle beneath Kamchatka, as derived from teleseismic tomography, can be explained by a gap in the Pacific Plate and lateral asthenospheric mantle flow around the slab edge (Jiang et al., 2009). High-resolution tomography also revealed that beneath Klyuchevskoy volcano, a near-vertical pipe-shaped conduit extends from 25 to $30 \mathrm{~km}$ depth to the summit which allows mantlederived mafic melts to ascend to the surface (Koulakov et al., 2017).

Eruptive products of Klyuchevskoy mainly consist of lavas and pyroclastics ranging from high$\mathrm{Mg}$, low-Al basalts to low-Mg, high-Al basaltic andesites (e.g., Ariskin et al., 1995; Bergal-Kuvikas et al., 2017; Kersting and Arculus, 1994; Khubunaya et al., 1993). For this study, olivine phenocrysts (Fo $>85$ ) from a high- $\mathrm{MgO}$ lava flow and tephra layer associated with the $\sim 3$ ky old Bulochka cinder cone on the NE flank of Klyuchevskoy volcano were selected. Olivine-hosted MIs are glassy in tephra samples and partially crystallized (i.e., with the presence of daughter pyroxene) in lava samples, and 
they all contain a fluid bubble and, occasionally, entrapped Cr-spinel (Figure 1a; Table 1; Mironov et al., 2015; Moore et al., 2018). The fluid bubbles are rich in $\mathrm{CO}_{2}$ and contain S-bearing phases (native S, sulfides or sulfates) and/or carbonates, as determined by Raman spectroscopy (Moore et al., 2018). Fluid bubbles occupy, on average, $4 \pm 2$ vol.\% within both glassy inclusions from tephra and inclusions heated dry from lavas (e.g. Moore et al., 2018); these rough estimates are based on 2D measurements of MIs (length, width, and thickness = width) and their bubbles (diameter). Importantly, previously studied MIs heated dry from Bulochka lavas and those used in re-hydration experiments show an excellent linear correlation between the volumes of MIs and their bubbles (with a narrow range of 3.9-6.4\% for the relative bubble volume) (e.g., Mironov and Portnyagin, 2011). This implies that, in the studied samples, homogeneous melts were trapped as MIs without the addition of any extra fluid (e.g. Mironov et al., 2020). The inclusions were presumably entrapped in olivine at $T=1150$ $1230^{\circ} \mathrm{C}, \log f \mathrm{O}_{2}=\mathrm{QFM}+0.8$ to +1.8 , and $P \geq 500 \mathrm{MPa}$ (see Mironov et al., 2015, for details). The trapping pressure (600-800 MPa) was estimated from the $\mathrm{H}_{2} \mathrm{O}-\mathrm{CO}_{2}$ concentrations in homogenized MIs and by extrapolating the experimental $\mathrm{H}_{2} \mathrm{O}-\mathrm{CO}_{2}$ solubility data for tholeiitic melts of Shishkina et al. (2010). Mironov et al. (2015) argued that these values agree well with independent estimates $(P>$ $500 \mathrm{MPa})$ based on the density of $\mathrm{CO}_{2}$-rich fluid inclusions $\left(\sim 0.8 \mathrm{~g} \mathrm{~cm}^{-3}\right)$ in high-Mg Klyuchevskoy olivine (Mironov and Portnyagin, 2011), as well as with petrological and modeling constraints for the crystallization conditions of magnesian Klyuchevskoy basalts (500-900 MPa in Kersting and Arculus (1994) and >700 MPa in Ariskin et al. (1995)).

\subsection{Experimental methods}

Homogenization experiments of olivine-hosted MIs were carried out at the Institute of Mineralogy, Leibniz University (Hanover, Germany), in vertically-oriented, internally-heated pressure vessels (IHPVs) equipped with a rapid quench device (see Mironov et al., 2015, for details). For the majority of the experiments, $\mathrm{Au}_{80} \mathrm{Pd}_{20}$ capsules $(20 \times 3 \mathrm{~mm})$, which were welded shut on one end, were loaded sequentially with powdered synthetic matrix glass (similar in major element composition to the Bulochka lavas and tephras; supplementary Table A.1.), 7-8 olivine grains $(0.5-1.25 \mathrm{~mm}$ in size), distilled $\mathrm{H}_{2} \mathrm{O}$, and powdered glass on top. The amount of $\mathrm{H}_{2} \mathrm{O}$ added varied between 5 and 11.3 wt. \% relative to the glass. A $20 \% \mathrm{NaCl}$ aqueous solution was added to the experiment $\# \mathrm{C} 4-4$. The use of different $\mathrm{H}_{2} \mathrm{O}$-bearing matrices permitted to study their effect on the diffusion rate of hydrogen in olivine (Mironov et al., 2015; Portnyagin et al., 2019). Once the top of the capsules was welded shut, they were weighed, heated to $110^{\circ} \mathrm{C}$ for $1 \mathrm{~h}$, and weighed again to check for leaks (i.e., to ensure that there had been no loss of fluid during heating). Two capsules (experiments \#C8-5 and \#C9) were charged with loose olivine grains only, without any matrix glass or fluid. For experiment \#C8-5, the top of the $\mathrm{Au}_{80} \mathrm{Pd}_{20}$ capsule remained open. For experiment \#C9, the olivine grains were placed into a small graphite container, which was encapsulated in Pt. The Pt capsule was welded shut on both ends. 
The $\mathrm{Au}_{80} \mathrm{Pd}_{20}$ capsules were kept in IHPVs at temperatures of $1150-1200^{\circ} \mathrm{C}$ and pressures of $300-500 \mathrm{MPa}$ for $24-28 \mathrm{~h}$, and then they were rapidly quenched $\left(\sim 150^{\circ} \mathrm{C} / \mathrm{s}\right)$. For the different experiments, the nominal oxygen fugacity varied between the intrinsic $f \mathrm{O}_{2}$ of the IHPV $\left(\log f \mathrm{O}_{2}=\right.$ $\mathrm{QFM}+3.3$ at $\mathrm{H}_{2} \mathrm{O}$-saturated conditions) and more reducing conditions ( $\left.\mathrm{QFM}+0.6\right)$ when the IHPV was pressurized with a Ar- $\mathrm{H}_{2}$ mixture. The experiment in the Pt capsule (\#C9) was carried out at an oxygen fugacity equal to $\mathrm{CCO}$ (where $\mathrm{CCO}$ is the graphite- $\mathrm{CO}-\mathrm{CO}_{2}$ oxygen buffer) at atmospheric pressure and a temperature of $1400^{\circ} \mathrm{C}$ for $1 \mathrm{~h}$.

Hereafter, MIs targeted for nitrogen abundance analyses are divided into three groups: 1) 'unheated' (natural) MIs in olivines that were extracted from tephra samples, 2) MIs in olivines from a lava flow that were 'heated $d r y$ ' (without any matrix glass or fluid), and 3) MIs from the same lava flow that were experimentally 'heated with $\mathrm{H}_{2} \mathrm{O}^{\prime}$ (with hydrous matrix and $\mathrm{H}_{2} \mathrm{O}$ or a $20 \% \mathrm{NaCl}$ aqueous solution) at high pressure (Figure 1).
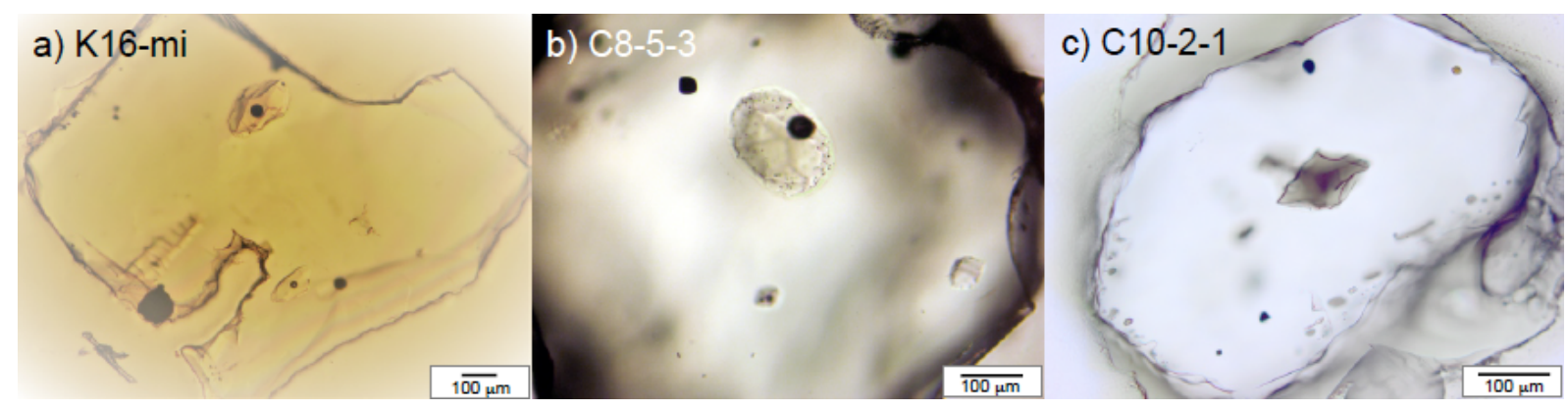

Figure 1: a) Unheated melt inclusion K16-mi, b) C8-5-3 heated dry at $300 \mathrm{MPa}$ and $1200^{\circ} \mathrm{C}$, and c) C10-2-1 heated with $\mathrm{H}_{2} \mathrm{O}$ at $500 \mathrm{MPa}$ and $1150^{\circ} \mathrm{C}$.

\subsection{Analytical methods}

Individual olivine grains containing natural or experimentally treated MIs were mounted in epoxy. The grains were grinded and polished to expose MIs on the surface using sand papers and diamond pastes of various particle sizes, and finally polished with a $0.25 \mu \mathrm{m}$ grain size $\mathrm{Al}_{2} \mathrm{O}_{3}$ suspension in water. The samples were then cleaned ultrasonically, removed from the epoxy mounts, and remounted in indium metal for further analyses.

For the study by Mironov et al. (2015), the MIs were analyzed for their $\mathrm{CO}_{2}$ and $\mathrm{H}_{2} \mathrm{O}$ content by SIMS (CAMECA IMS $1280 \mathrm{HR}$ ) at CRPG (Nancy, France). Subsequently, the inclusions were analyzed for major elements, S, and $\mathrm{Cl}$ by electron microprobe (JEOL JXA 8200) at GEOMAR (Kiel, Germany) and for trace elements (Ti, Nb, Ba, La, Th) by SIMS (CAMECA IMS 4f) at the Yaroslavl Branch of the Institute of Physics and Technology (Yaroslavl, Russia). Details on the analytical techniques and the compositions of MIs, matrix glass, and host rocks are provided by Mironov et al. (2015). The results are summarized in supplementary Table A.1., together with unpublished data for four additional MIs. Information directly relevant for this study, such as the size of MIs, the volume of 
the bubble relative to the total $\mathrm{MI}$ volume, and the $\mathrm{CO}_{2}$ and $\mathrm{H}_{2} \mathrm{O}$ concentrations in the glasses, is given in Table 1.

For this study, nitrogen $\left({ }^{14} \mathrm{~N}\right)$ abundances were determined with the CAMECA IMS $1280 \mathrm{HR}$ at CRPG. Spot-analyses of ${ }^{14} \mathrm{~N}^{16} \mathrm{O}^{-}$secondary molecular ions were carried out in mono-collection mode on an electron multiplier at a nominal mass resolution $m / \Delta m \approx 14,000$ using a $10 \mathrm{kV} \mathrm{Cs}{ }^{+}$ primary ion beam with a current of $10 \mathrm{nA}$ and a spot diameter of $\sim 20 \mu \mathrm{m}$, following the analytical protocol of Füri et al. (2018). The ${ }^{30} \mathrm{Si}^{-}$and ${ }^{16} \mathrm{O}_{2}{ }^{-}$count rates were determined on a Faraday cup (FC2) during each cycle to monitor the stability of secondary ion intensities. In addition, the ${ }^{27} \mathrm{Al}^{-}$signal was monitored to distinguish MIs from their host olivine. Following pre-sputtering for $180 \mathrm{~s}$ with a beam raster of $10 \times 10 \mu \mathrm{m}$ to minimize any surface contamination prior to signal acquisition, twenty cycles were collected for each analysis through the mass sequence ${ }^{27} \mathrm{Al}^{-}(3 \mathrm{~s}),{ }^{30} \mathrm{Si}^{-}(3 \mathrm{~s}),{ }^{14} \mathrm{~N}^{16} \mathrm{O}^{-}(6 \mathrm{~s})$, ${ }^{15} \mathrm{~N}^{16} \mathrm{O}^{-}(20 \mathrm{~s})$, and ${ }^{16} \mathrm{O}_{2}^{-}(3 \mathrm{~s})$. Repeat analyses $(n=75)$ of eight synthetic basaltic glasses from Humbert (1998), containing between $<1$ and $3906 \pm 188$ ppm N, were used to calibrate the secondary ion intensity ratio ${ }^{14} \mathrm{~N}^{16} \mathrm{O}^{-} /{ }^{16} \mathrm{O}_{2}^{-}$to the nitrogen contents. This approach has been demonstrated to yield nitrogen concentrations in silicate glasses of variable compositions that are in excellent agreement with results from static mass spectrometry analyses, even for nitrogen concentrations at the (sub-)ppm level (Boulliung et al., 2020). The method, however, does not allow us to determine which nitrogen species (e.g., $\mathrm{N}_{2}, \mathrm{~N}_{\mathrm{x}} \mathrm{H}_{\mathrm{x}}$ ) contribute(s) to the measured ${ }^{14} \mathrm{~N}^{16} \mathrm{O}^{-}$signal.

Secondary ion intensities measured by SIMS are reported in supplementary Table A.2. Duplicate analyses of large MIs (C4-2-1a and C10-2-1) yielded ${ }^{14} \mathrm{~N}^{16} \mathrm{O}^{-} /{ }^{16} \mathrm{O}_{2}^{-}$ratios (and calculated $\mathrm{N}$ contents) that are in good agreement. All measured ${ }^{15} \mathrm{~N}^{16} \mathrm{O}^{-}$signals were very low ( $\left.\leq 4.6 \mathrm{cps}\right)$, and, given the high water content of the inclusions, they were likely affected by the tail of the neighboring ${ }^{29} \mathrm{SiH}_{2}^{-}$peak; therefore, ${ }^{15} \mathrm{~N}^{16} \mathrm{O}^{-}$count rates are not reported, and nitrogen isotope ratios $\left({ }^{15} \mathrm{~N} /{ }^{14} \mathrm{~N}\right)$ could not be determined. We also note that host olivines (e.g., C4-2-1, C4-3-1, C10-2-1, C9-3, and K6), which can clearly be distinguished from glass inclusions based on their low ${ }^{27} \mathrm{Al}^{-}$signals, contained no detectable nitrogen, i.e., ${ }^{14} \mathrm{~N}^{16} \mathrm{O}^{-}$count rates $(2-3 \mathrm{cps})$ were equal to or lower than those of the calibrant containing $0.022 \pm 0.034 \mathrm{ppm} \mathrm{N}(3-4 \mathrm{cps}, n=12)$.

\section{Results}

Previous analyses revealed that the glass phase of unheated, glassy, bubble-bearing MIs from Bulochka tephra contains between 2.9 and 3.4 wt. $\% \mathrm{H}_{2} \mathrm{O}$ and 880 to 1200 ppm $\mathrm{CO}_{2}$ (Figure 2a,b; Table 1; Mironov et al., 2015). Heating of initially re-crystallized and predominantly dry MIs from lavas in the presence of $\mathrm{H}_{2} \mathrm{O}$ at a pressure of $300 \mathrm{MPa}$ results in higher $\mathrm{H}_{2} \mathrm{O}$ and $\mathrm{CO}_{2}$ abundances (i.e., up to $5.2 \mathrm{wt} . \%$ and $3700 \mathrm{ppm} \mathrm{CO}_{2}$ ) in the glass phase. Although the volume of the fluid bubble decreased as a result of the experimental treatment, most of these MIs still contain a residual bubble of variable size, suggesting that volatiles initially present in the fluid bubble were not completely redissolved into the melt. Complete homogenization (i.e., disappearance of the fluid bubble) was 
achieved for the most hydrated inclusions at a pressure of $500 \mathrm{MPa}$, resulting in the highest observed $\mathrm{H}_{2} \mathrm{O}$ and $\mathrm{CO}_{2}$ contents of 4.6-5.6 wt.\% and 3800-4800 ppm, respectively, in the quenched glass. Overall, the hydrous high-pressure experiments resulted in gradual shrinking of the fluid bubble up to its complete dissolution, and a concomitant increase in $\mathrm{H}_{2} \mathrm{O}$ and $\mathrm{CO}_{2}$ concentrations in the melt (Mironov et al., 2015). These observations are consistent with the notion that a large amount of volatiles partitioned into the fluid phase of bubble-bearing inclusions (and/or, in the case of $\mathrm{H}_{2} \mathrm{O}$, was lost by diffusion through the host crystal). Inclusions heated dry, in contrast, contain significantly less $\mathrm{H}_{2} \mathrm{O}$ and $\mathrm{CO}_{2}$ in the quenched glass, and the volume of the fluid bubble is larger than that of the MIs treated in the presence of $\mathrm{H}_{2} \mathrm{O}$. These observations suggest that $\mathrm{MI}$ heating without re-hydration has a distinct effect on the volatile characteristics of the melt.
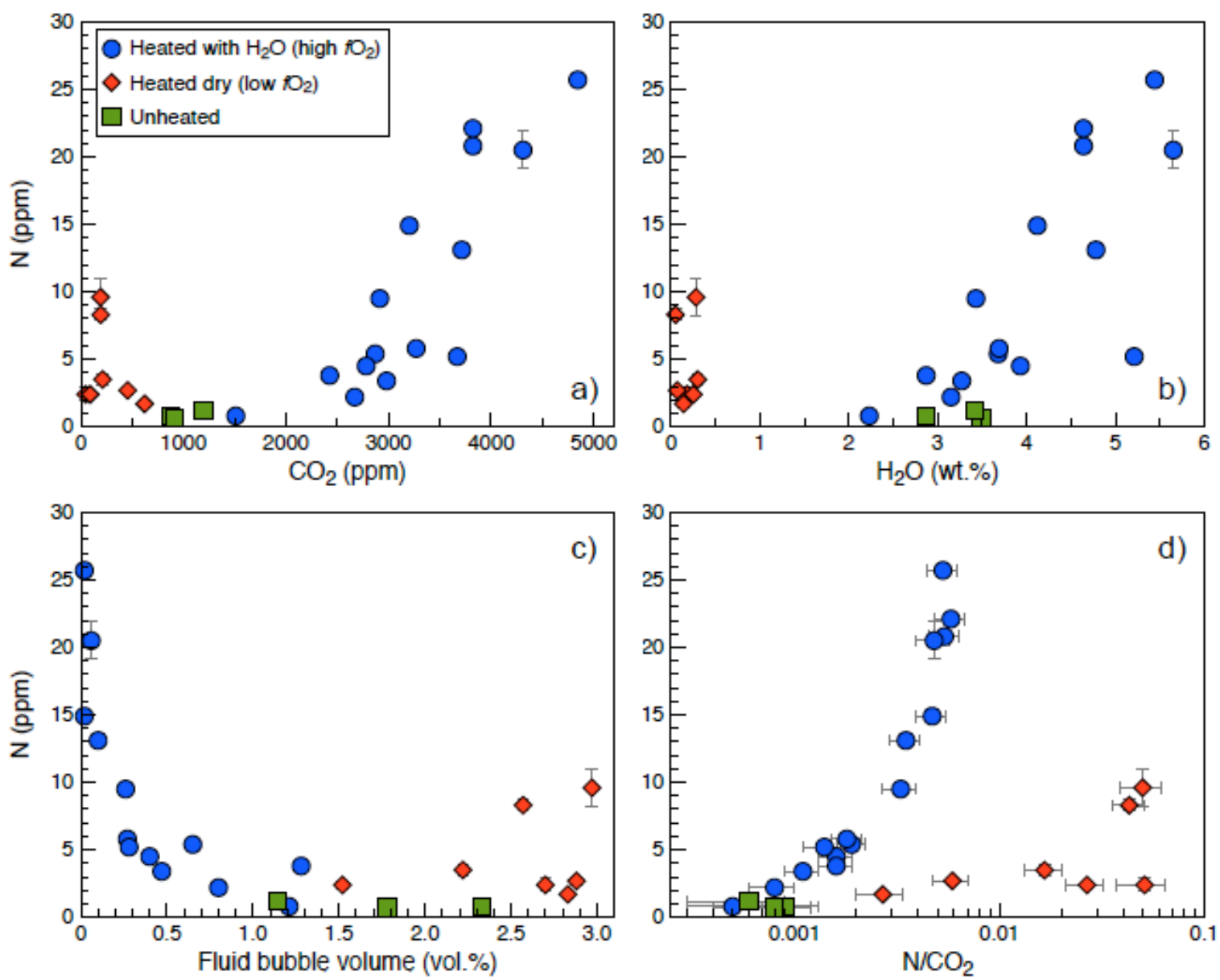

Figure 2: Nitrogen concentration in the glass phase of Klyuchevskoy MIs versus a) the $\mathrm{CO}_{2}$ content of the glass phase, $b$ ) the $\mathrm{H}_{2} \mathrm{O}$ content of the glass phase, c) the (residual) fluid bubble volume (relative to the total volume of the inclusion), and d) the $\mathrm{N} / \mathrm{CO}_{2}(\mathrm{ppm} / \mathrm{ppm})$ ratio. Uncertainties of SIMS nitrogen concentration measurements are $2 \sigma$ and are, in most cases, smaller than symbol sizes.

The glass phase of unheated MIs from Bulochka tephra contains a small amount of nitrogen, i.e., $0.8 \pm 0.3$ to $1.2 \pm 0.3 \mathrm{ppm} \mathrm{N}$ (Figure 2; Table 1). The $\mathrm{N}$ concentration in MIs heated dry (at $\log f \mathrm{O}_{2}=\mathrm{QFM}+0.6$ or $\mathrm{CCO}$ ) varies between $1.7 \pm 0.3$ and $9.6 \pm 1.4 \mathrm{ppm}$. Notably, these MIs were not 
completely homogenized (i.e., they still contain a bubble with a relative volume of 1.5 to $3 \%$ after the experiments; Figure 2c); consequently, a significant fraction of $\mathrm{N}$ and $\mathrm{CO}_{2}$ must have remained in the fluid phase. It is noteworthy that their dissolved $\mathrm{N}$ contents are higher than those of unheated inclusions with large fluid bubbles, and Figure 2d shows that the glasses of these inclusions are characterized by exceptionally high $\mathrm{N} / \mathrm{CO}_{2}$ ratios (as high as $0.05 \pm 0.01$ ).

Inclusions that were experimentally re-hydrated at $P=300 \mathrm{MPa}$ and $\log f \mathrm{O}_{2}=\mathrm{QFM}+3.3$ contain $0.8 \pm 0.3$ to $14.9 \pm 0.5 \mathrm{ppm} \mathrm{N}$ in the quenched glass. The highest $\mathrm{N}$ abundances of up to $25.7 \pm 0.5$ ppm were observed in the most hydrated MIs that were completely homogenized at $500 \mathrm{MPa}$. Nitrogen concentrations of MIs heated with $\mathrm{H}_{2} \mathrm{O}$ clearly correlate with $\mathrm{CO}_{2}$ and $\mathrm{H}_{2} \mathrm{O}$ abundances in the glass phase (Figure 2a and b). In parallel, the $\mathrm{N}$ content is related to the volume of the residual fluid bubble (Figure 2c), i.e., a reduction of the bubble volume results in increased dissolved $\mathrm{N}$ concentrations. Finally, Figure $2 \mathbf{d}$ shows that the $\mathrm{N} / \mathrm{CO}_{2}$ ratio progressively increases from a minimum value of $\sim 0.0005$ towards $0.005 \pm 0.001$ as a result of homogenization.

Table 1: Experimental conditions and volatile $\left(\mathrm{N}, \mathrm{H}_{2} \mathrm{O}, \mathrm{CO}_{2}\right)$ contents of olivine-hosted melt inclusions from Klyuchevskoy volcano.

\begin{tabular}{|c|c|c|c|c|c|c|c|}
\hline Sample ID & Conditions & Phases in MI & $\begin{array}{c}\text { D } \\
(\mu \mathrm{m})\end{array}$ & $\begin{array}{c}\text { FB } \\
(\text { vol. } \%)\end{array}$ & $\begin{array}{c}\mathrm{N} \\
(\mathbf{p p m})\end{array}$ & $\begin{array}{c}\mathrm{CO}_{2} \\
(\mathbf{p p m})\end{array}$ & $\begin{array}{c}\mathrm{H}_{2} \mathrm{O} \\
(\mathbf{w t .} \%)\end{array}$ \\
\hline C4-1-1 & \multirow{3}{*}{$\begin{array}{l}300 \mathrm{MPa}, 1150^{\circ} \mathrm{C}, 24 \mathrm{~h}, \mathrm{QFM}+3.3 \\
\text { matrix glass }+9.3 \% \mathrm{H}_{2} \mathrm{O}\end{array}$} & $\mathrm{g}, \mathrm{f}, \mathrm{sp}$ & 100 & $<0.1$ & $14.9 \pm 0.5$ & 3202 & 4.12 \\
\hline C4-1-2 & & $\mathrm{g}, \mathrm{f}$ & 107 & 0.7 & $5.4 \pm 0.3$ & 2869 & 3.68 \\
\hline C4-1-3 & & $\mathrm{g}, \mathrm{f}$ & 100 & 0.1 & $13.1 \pm 0.5$ & 3713 & 4.78 \\
\hline C4-2-1a & \multirow{4}{*}{$\begin{array}{l}300 \mathrm{MPa}, 1150^{\circ} \mathrm{C}, 24 \mathrm{~h}, \mathrm{QFM}+3.3 \\
\text { matrix glass }+5 \% \mathrm{H}_{2} \mathrm{O}\end{array}$} & $\mathrm{g}, \mathrm{f}, \mathrm{sp}, \mathrm{cpx}$ & 125 & 0.5 & $3.4 \pm 0.3$ & 2980 & 3.27 \\
\hline & & & & & $3.4 \pm 0.3$ & & \\
\hline C4-2-1b & & $\mathrm{g}, \mathrm{f}, \mathrm{sp}$ & 90 & 0.3 & $5.8 \pm 0.3$ & 3269 & 3.69 \\
\hline C4-2-2 & & $\mathrm{g}, \mathrm{f}, \mathrm{sp}$ & 79 & 0.4 & $4.5 \pm 0.3$ & 2781 & 3.93 \\
\hline C4-3-1 & \multirow{2}{*}{$\begin{array}{l}300 \mathrm{MPa}, 1150^{\circ} \mathrm{C}, 24 \mathrm{~h}, \mathrm{QFM}+3.3 \\
\text { matrix glass }+11.3 \% \mathrm{H}_{2} \mathrm{O}\end{array}$} & $\mathrm{g}, \mathrm{f}, \mathrm{sp}$ & 138 & 0.3 & $9.5 \pm 0.4$ & 2914 & 3.43 \\
\hline C4-3-2 & & $\mathrm{g}, \mathrm{f}$ & 57 & 0.3 & $5.2 \pm 0.3$ & 3669 & 5.21 \\
\hline C4-4-2 & \multirow{3}{*}{$\begin{array}{l}300 \mathrm{MPa}, 1150^{\circ} \mathrm{C}, 24 \mathrm{~h}, \mathrm{QFM}+3.3 \\
\text { matrix glass }+20 \% \mathrm{NaCl}\end{array}$} & $\mathrm{g}, \mathrm{f}, \mathrm{sp}$ & 112 & 1.3 & $3.8 \pm 0.3$ & 2425 & 2.87 \\
\hline C4-4-3 & & $\mathrm{g}, \mathrm{f}$ & 153 & 1.2 & $0.8 \pm 0.3$ & 1510 & 2.23 \\
\hline C4-4-5 & & $\mathrm{g}, \mathrm{f}$ & 80 & 0.8 & $2.2 \pm 0.3$ & 2670 & 3.15 \\
\hline C8-5-1* & \multirow{4}{*}{$\begin{array}{l}300 \mathrm{MPa}, 1200^{\circ} \mathrm{C}, 28 \mathrm{~h}, \mathrm{QFM}+0.6 \\
\text { no matrix }\end{array}$} & $\mathrm{g}, \mathrm{f}, \mathrm{s}$ & 80 & 2.7 & $2.4 \pm 0.5$ & 47 & 0.18 \\
\hline C8-5-3 & & $\mathrm{g}, \mathrm{f}, \mathrm{s}$ & 113 & 1.5 & $2.4 \pm 0.3$ & 90 & 0.25 \\
\hline$C 8-5-4 a$ & & $g, f, s$ & 89 & 2.2 & $3.5 \pm 0.4$ & 211 & 0.30 \\
\hline C8-5-4b* & & $\mathrm{g}, \mathrm{f}, \mathrm{s}$ & 84 & 3.0 & $9.6 \pm 1.4$ & 192 & 0.28 \\
\hline C9-1 & \multirow{3}{*}{$\begin{array}{l}1 \text { atm, } 1400^{\circ} \mathrm{C}, 1 \mathrm{~h}, \mathrm{CCO} \\
\text { no matrix }\end{array}$} & $\mathrm{g}, \mathrm{f}, \mathrm{s}$ & 105 & 2.8 & $1.7 \pm 0.3$ & 621 & 0.14 \\
\hline C9-2 & & $\mathrm{g}, \mathrm{f}, \mathrm{s}, \mathrm{sp}$ & 61 & 2.6 & $8.3 \pm 0.4$ & 193 & 0.05 \\
\hline $\mathrm{C} 9-3$ & & $\mathrm{~g}, \mathrm{f}, \mathrm{s}$ & 75 & 2.9 & $2.7 \pm 0.3$ & 456 & 0.07 \\
\hline C10-2-1 & \multirow{4}{*}{$\begin{array}{l}500 \mathrm{MPa}, 1150^{\circ} \mathrm{C}, 24 \mathrm{~h}, \mathrm{QFM}+0.6 \\
\text { matrix glass }+5.6 \% \mathrm{H}_{2} \mathrm{O}\end{array}$} & $\mathrm{g}, \mathrm{s}, \mathrm{sp}$ & 106 & 0 & $20.8 \pm 0.5$ & 3822 & 4.64 \\
\hline & & & & & $22.1 \pm 0.4$ & & \\
\hline C10-2-3* & & $\mathrm{g}, \mathrm{s}, \mathrm{sp}$ & 70 & $<0.1$ & $20.5 \pm 1.4$ & 4310 & 5.65 \\
\hline C10-2-5* & & $\mathrm{g}, \mathrm{s}, \mathrm{sp}$ & 88 & $<0.1$ & $25.7 \pm 0.5$ & 4844 & 5.44 \\
\hline K6-mil & \multirow{3}{*}{ Natural } & $g, f, s p$ & 88 & 2.3 & $0.8 \pm 0.3$ & 879 & 2.87 \\
\hline K6-mi2 & & $\mathrm{g}, \mathrm{f}, \mathrm{sp}$ & 288 & 1.8 & $0.7 \pm 0.3$ & 911 & 3.49 \\
\hline K16-mi & & $\mathrm{g}, \mathrm{f}, \mathrm{sp}$ & 178 & 1.1 & $1.2 \pm 0.3$ & 1198 & 3.42 \\
\hline
\end{tabular}

Notes: $\mathrm{g}$ - glass; $\mathrm{f}$ - fluid; sp - Cr-spinel; cpx - clinopyroxene; $\mathrm{s}$ - sulfide; D - average two-dimensional diameter of the melt inclusion; FB - volume of the residual fluid bubble relative to the total volume of the inclusion. $\mathrm{N}$ concentrations were determined in this study, whereas the size of MIs and their $\mathrm{H}_{2} \mathrm{O}$ and $\mathrm{CO}_{2}$ contents are from Mironov et al. (2015) (with the exception of the four MIs marked with asterisks). Uncertainties $(2 \sigma)$ of $\mathrm{CO}_{2}$ and $\mathrm{H}_{2} \mathrm{O}$ concentrations, determined by SIMS, are estimated to be $17 \%$ and $9 \%$, respectively (supplementary Table A.1). 


\section{Discussion}

\subsection{Effects of the experimental treatment on $\mathbf{N}$ concentrations in melt inclusions}

Previous experimental studies of olivine-hosted MIs from Klyuchevskoy volcano (Mironov et al., 2015; Portnyagin et al., 2019) revealed that homogenization at high $P$ and high $T$ in the presence of $\mathrm{H}_{2} \mathrm{O}$ results in $\mathrm{H}^{+}$diffusion through the olivine structure and re-hydration of the melt. The rapid diffusion of hydrogen in Klyuchevskoy olivines is primarily controlled by metal $(\mathrm{Mg}, \mathrm{Fe})$ vacancies, as confirmed by FTIR spectroscopy, with a $\mathrm{H}$ diffusivity $\left(D_{\mathrm{H}}\right)$ on the order of $10^{-11} \mathrm{~m}^{2} \mathrm{~s}^{-1}$ at $1200^{\circ} \mathrm{C}$. As a consequence of $\mathrm{H}^{+}$diffusion through olivine and an increasing $\mathrm{H}_{2} \mathrm{O}$ content in the trapped melt, the pressure inside MIs increases, thereby causing dissolution of $\mathrm{CO}_{2}$ from the fluid bubble back into melt. Since the diffusivity of $\mathrm{C}$ in olivine has been shown to be very low (i.e., $<10^{-16} \mathrm{~m}^{2} \mathrm{~s}^{-1}$ at $P \leq 3$ GPa and $T=1200-1450^{\circ} \mathrm{C}$; Tingle et al., 1988), the $\mathrm{C}$ content of the melt is not expected to be modified by inward or outward diffusion through the host crystal during the experiments.

The results of this study reveal that the experimental treatment results in increasing $\mathrm{N}$ concentrations, as well as high $\mathrm{N} / \mathrm{CO}_{2}$ ratios, in the glass phase of MIs that were heated with a fluid and hydrous matrix in closed capsules. In contrast, glasses of the dry runs contain a significantly lower amount of $\mathrm{H}_{2} \mathrm{O}$ and $\mathrm{CO}_{2}$ than those of unheated (natural) MIs, and they record anomalously high $\mathrm{N} / \mathrm{CO}_{2}$ ratios (Figure 2d). These observations indicate that the experimental treatment can have a variable effect on the volatile element systematics of MIs. In either case, the data may imply that 1) MIs are enriched in $\mathrm{N}$ as a result of inward $\mathrm{N}$ diffusion through the host olivine, or, alternatively, 2) a significant amount of $\mathrm{N}$ was stored in the fluid bubble together with $\mathrm{CO}_{2}$ prior to the experiments, and is re-dissolved into the melt at high $P$ and high $T$. These two hypotheses are discussed below.

\subsubsection{Inward diffusion of $N$}

The open capsule of the dry experiment \#C8-5 was exposed to a $\mathrm{Ar}-\mathrm{H}_{2}$ gas mixture in the IHPV; for this run series, an external source for $\mathrm{N}$ detected in the olivine-hosted MIs can be ruled out. In contrast, for the hydrous experiments in closed capsules, olivine grains were in contact with synthetic matrix glass and a fluid $\left(\mathrm{H}_{2} \mathrm{O}\right.$ or a $20 \% \mathrm{NaCl}$ aqueous solution), whose $\mathrm{N}$ content is unknown. In addition, a small amount of air was likely trapped in the capsules of these run series and the dry run series \#C9 during loading and welding. Since the olivines were in contact with sources variably enriched in $\mathrm{N}$ (gas, matrix, fluid) at high temperatures, the possibility of inward diffusion of $\mathrm{N}$ through the olivine structure must be explored.

Nitrogen (in-)diffusion in San Carlos olivine was recently studied by Watson et al. (2019) through experiments at $T=650-1400^{\circ} \mathrm{C}$ and $P=0.001-1 \mathrm{GPa}$. The results revealed that the $\mathrm{N}$ diffusivity $\left(D_{\mathrm{N}}\right)$ in olivine varies between $10^{-19.2} \mathrm{~m}^{2} \mathrm{~s}^{-1}$ and $10^{-18.4} \mathrm{~m}^{2} \mathrm{~s}^{-1}$ at temperatures of $1150^{\circ} \mathrm{C}$ and $1400^{\circ} \mathrm{C}$, respectively, and that the diffusing species is either molecular $\mathrm{N}_{2}$ or monatomic $\mathrm{N}$. It is noteworthy that these experiments were carried out by $\mathrm{N}^{+}$ion implantation ( $\left.\sim 900 \mathrm{ppm}\right)$ followed by heating to mobilize $\mathrm{N}$, and they resulted in high near-surface ${ }^{15} \mathrm{~N}$ concentrations between $\sim 50$ and 270 
ppm in olivine, as determined by nuclear reaction analysis. In contrast, SIMS analysis shows that the $\mathrm{N}$ content of Klyuchevskoy olivines is below the detection limit (i.e., ${ }^{14} \mathrm{~N}^{16} \mathrm{O}^{-}$count rates were comparable to those of the reference glass containing $0.022 \pm 0.034 \mathrm{ppm} \mathrm{N}$ ) following the homogenization experiments. Most importantly, since nitrogen diffusion is eight orders of magnitude slower than $\mathrm{H}^{+}$diffusion, the $\mathrm{N}$ contents of the studied MIs are unlikely to be affected by diffusion on timescales of $1-28 \mathrm{~h}$.

Similar amounts of N (1.7-9.6 ppm; Figure 2; Table 1) are detected in the glass phase of MIs heated dry in the presence of trapped air (\#C9) or in a N-poor $\mathrm{Ar}-\mathrm{H}_{2}$ atmosphere (\#C8-5). Most importantly, the $\mathrm{N}$ contents of inclusions within olivine grains that were heated in contact with $\mathrm{N}$ bearing matrix glass and a fluid range from very low to the highest values ( 0.8 to $25.7 \mathrm{ppm} \mathrm{N}$ ), and they are clearly correlated with $\mathrm{H}_{2} \mathrm{O}$ and $\mathrm{CO}_{2}$ concentrations. These observations demonstrate that there is no direct relationship between the $\mathrm{N}$ concentrations in MI glasses and any $\mathrm{N}$ that may be present in the different matrices the host olivines interacted with (gas, matrix, fluid). Based on the available data, we therefore conclude that the elevated $\mathrm{N}$ abundances in MIs are unlikely to be the result of contamination by inward migration of $\mathrm{N}$ from the surrounding gas, matrix or fluid through olivine by either diffusion or transport along dislocations in the crystal structure.

\subsubsection{Dissolution of $N$ from the fluid bubble back into the melt}

Given that inward diffusion of $\mathrm{N}$ can be ruled out as the cause of high $\mathrm{N}$ concentrations in homogenized olivine-hosted MIs from Klyuchevskoy volcano, the results of this study imply that a significant amount of $\mathrm{N}$ partitioned into the fluid phase during decompression and bubble growth within the inclusions after entrapment in olivine, and that $\mathrm{N}$ dissolved back into the melt as a result of the experimental treatment. Importantly, the strong negative correlation between the $\mathrm{N}$ content of the melt and the fluid bubble volume for MIs heated with $\mathrm{H}_{2} \mathrm{O}$ (Figure 2c) indicates a closed-system behavior of the MIs, i.e., all $\mathrm{N}$ was initially stored inside the inclusions, within which it was partitioned between the melt and fluid bubble. According to this scenario, the observed significant increase of the $\mathrm{N} / \mathrm{CO}_{2}$ ratio in the melt with progressive MI re-hydration implies that the fluid-melt partition coefficient of $\mathrm{N}$ is higher than that of $\mathrm{CO}_{2}$.

The volatile compositions of MIs heated dry deviate from the trend defined by inclusions heated with $\mathrm{H}_{2} \mathrm{O}$ towards anomalously high $\mathrm{N} / \mathrm{CO}_{2}$ at a given $\mathrm{N}$ content (Figure 2d). These distinct $\mathrm{N}$ $\mathrm{CO}_{2}-\mathrm{H}_{2} \mathrm{O}$ systematics can be explained, in part, by different $f \mathrm{O}_{2}$ (and $T$, for \#C9) conditions compared to the hydrous runs; lower $f \mathrm{O}_{2}$ has an important effect on $\mathrm{N}$ solubility in silicate melts (Section 4.2; Boulliung et al., 2020; Bernardou et al., 2021; Grewal et al., 2020; Libourel et al., 2003; Roskosz et al., 2006; Li et al. 2015). The dry \#C9 run series was carried out at $1 \mathrm{~atm}$, nominally reducing conditions $\left(\log f \mathrm{O}_{2}=\mathrm{CCO}\right)$, and at a higher temperature of $1400^{\circ} \mathrm{C}$ than the hydrous experiments, whereas the $f \mathrm{O}_{2}$ and $T$ conditions during the dry high-pressure experiment \#C8-5 (QFM+0.6 and 1200 ${ }^{\circ} \mathrm{C}$ ) were comparable to those run with hydrous matrix and $\mathrm{H}_{2} \mathrm{O}$ (Table 1). However, the nominal 
oxygen fugacity $\log f \mathrm{O}_{2}=\mathrm{QFM}+0.6$ corresponds to the water-saturated system, and, hence, dehydration of MIs in this dry experiment may have shifted the actual redox conditions to more reducing. Depending on the amount of water remaining in the \#C8-5 MIs, the $\log f \mathrm{O}_{2}$ within these inclusions may be lower than the nominal QFM +0.6 value by up to 2 logarithmic units. Furthermore, since the dry experiments in open $\mathrm{Au}_{80} \mathrm{Pd}_{20}$ (\#C8-5) and Pt capsules (\#C9) resulted in melt dehydration (Figure 2b) due to the contrast in water activity between the interior and exterior of the heated MIs, the internal pressure in the MIs decreased, assuming that the volume of MIs remained constant. Consequently, $\mathrm{CO}_{2}$ partitioned into the expanding fluid bubble to compensate for the decreasing pressure and increasing $\mathrm{CO}_{2}$ fugacity. This redistribution process reduced the $\mathrm{CO}_{2}$ concentration in the melt phase. The process of $\mathrm{CO}_{2}$ exsolution from the melt and growth of a large bubble containing a $\mathrm{CO}_{2}$-dominated fluid, accompanied by reducing $f \mathrm{O}_{2}$ in the melt, may have modified $\mathrm{N}$ speciation in the fluid as well as $\mathrm{N}$ solubility and dissolution mechanism(s) in the melt.

Overall, this study reveals that the widely used technique of MI heating without re-hydration can produce complex $\mathrm{N}-\mathrm{CO}_{2}-\mathrm{H}_{2} \mathrm{O}$ interactions because the loss of water from the MIs might affect the speciation and behavior of all other volatiles and prevent complete homogenization. Since $\mathrm{N}$ in the seven MIs heated dry shows a peculiar behavior, which leads to increased $\mathrm{N} / \mathrm{CO}_{2}$ ratios in melts that are in contact with large fluid bubbles, the $\mathrm{N}-\mathrm{CO}_{2}$ characteristics of the glasses of dehydrated MIs are not representative of either those of the primary melt or partially degassed melts that existed in nature. In contrast, the highest $\mathrm{N}$ and $\mathrm{CO}_{2}$ concentrations observed here in completely homogenized, rehydrated MIs represent a good proxy for the volatile characteristics of the most primitive Klyuchevskoy melt. Since it cannot be excluded that some volatiles were lost from the melt by degassing prior to the entrapment of inclusions by the host mineral phase, these measured values may represent minimum primary (i.e., mantle-derived) melt $\mathrm{N}$ and $\mathrm{CO}_{2}$ contents. Similarly, if degassing occurred prior to melt entrapment, the observed $\mathrm{N} / \mathrm{CO}_{2}$ ratios would be minimum values, assuming that the fluid-melt partition coefficient of $\mathrm{N}$ is higher than that of $\mathrm{CO}_{2}$.

\section{2. $\mathrm{N}$ partitioning between fluid and melt in Klyuchevskoy magmas}

Experimental investigations revealed that $\mathrm{N}$ solubility in silicate melts is primarily controlled by the oxygen fugacity $\left(f \mathrm{O}_{2}\right)$; in addition, the chemical composition of the melt (i.e., the degree of melt polymerization), the hydrogen fugacity $\left(f \mathrm{H}_{2}\right)$, and the $P-T$ conditions also affect $\mathrm{N}$ solubility (Boulliung et al., 2020; Bernadou et al., 2021; Dalou et al., 2019a, 2019b; Fogel, 1994; Grewal et al., 2020, 2019; Kadik et al., 2015, 2011; Li et al., 2015; Libourel et al., 2003; Mallik et al., 2018; Miyazaki et al., 2004; Mosenfelder et al., 2019; Mulfinger, 1966; Mysen and Fogel, 2010; Roskosz et al., 2013, 2006). At atmospheric pressure and under reducing conditions, $\mathrm{N}$ chemically bonds into the silicate network in high concentration (up to $\sim 3000$ and $6000 \mathrm{ppm} \mathrm{N}$ in andesitic or basaltic melts, respectively, at IW -8 and $1425^{\circ} \mathrm{C}$; Boulliung et al., 2020). In contrast, under oxidizing conditions (IW $\geq-1$ ), $\mathrm{N}$ is 'physically' incorporated in very low concentrations ( $\leq 1 \mathrm{ppm})$ in the form of $\mathrm{N}_{2}$ molecules 
into cavities of the silicate melt network without the formation of covalent or ionic bonds (Boulliung et al., 2020; Libourel et al., 2003; Miyazaki et al., 2004); this dissolution mechanism is comparable to that of the noble gases (e.g., Paonita, 2005). Under either reducing or oxidizing conditions, N solubility in silicate melts increases with increasing pressure, at least for pressures up to 4-5 GPa (Roskosz et al., 2013, 2006).

Considering the $P-T-f \mathrm{O}_{2}$ conditions of the mantle wedge beneath convergent margins, nitrogen is expected to predominantly dissolve as $\mathrm{N}_{2}$ in sub-arc mantle melts, although some nitrogen can exist as various N-H complexes (Li et al., 2015; Mallik et al., 2018; Mikhail and Sverjensky, 2015; Mysen, 2019; Mysen et al., 2008). Accordingly, dissolved $\mathrm{N}_{2}$ is a "passive" volatile element that strongly partitions into the fluid phase during magma decompression (Watson, 2017). During degassing, dissolved $\mathrm{N}_{2}$ and $\mathrm{CO}_{2}$ are then expected to be fractionated according to their relative solubilities, where $S_{\mathrm{N} 2}=2.2 \pm 0.5 \times 10^{-9} \mathrm{~mol} \mathrm{~g}^{-1}$ bar $^{-1}$ (Libourel et al., 2003) and $S_{\mathrm{CO} 2}=9.3 \times 10^{-9} \mathrm{~mol} \mathrm{~g}^{-1} \mathrm{bar}^{-1}$ (Burnard, 2001; Dixon, 1997; Dixon et al., 1995) as determined for nominally anhydrous tholeiitic melts at $1425^{\circ} \mathrm{C}$ and $1200^{\circ} \mathrm{C}$, respectively, by gas-melt equilibration at atmospheric pressure. (We note here that slightly variable solubility values - in units of $\mathrm{cm}^{3} \mathrm{STP} \mathrm{g}^{-1} \mathrm{bar}^{-1}, \mathrm{ppm} \mathrm{atm}^{-1}$ or mol g $\mathrm{hPa}^{-1}$ - are reported in the literature; e.g., Boulliung et al., 2020; Cartigny et al., 2001; Marty et al., 2020). Consequently, the $\mathrm{N}_{2} / \mathrm{CO}_{2}$ ratio in the residual melt is expected to decrease during (closed- or open-system) degassing en route to the surface (e.g., Burnard, 2001; Marty, 1995; Marty and Zimmermann, 1999), whereas the $\mathrm{N}_{2} / \mathrm{CO}_{2}$ ratio in the exsolving gas phase will be higher than that of the melt. In this respect, it is noteworthy that Taran (2009) measured a molar $\mathrm{N}_{2} / \mathrm{CO}_{2}$ ratio of $\sim 0.03$ (i.e., $\mathrm{CO}_{2} / \mathrm{N}_{2}=32$, corrected for atmospheric contamination) in volcanic gases at Klyuchevskoy volcano during eruption in 1994. This value is $\sim 4$ times higher than the ratio determined here for the primary melt based on MI data (i.e., molar $\mathrm{N}_{2} / \mathrm{CO}_{2} \approx 0.008$, assuming that all $\mathrm{N}$ is dissolved as $\mathrm{N}_{2}$ ), consistent with the notion that degassing of sub-arc melts will result in higher $\mathrm{N}_{2} / \mathrm{CO}_{2}$ ratios in the exsolving gas phase. However, given that the $\mathrm{N}_{2} / \mathrm{CO}_{2}$ ratio of volcanic and hydrothermal gas discharges is controlled by the $P-T-f \mathrm{O}_{2}\left(-f \mathrm{H}_{2}\right)$ conditions and the fractionation style and extent of degassing, as well as by additional processes such as the volatile input from the arc crust (Hilton et al., 2002) and calcite precipitation (Ray et al., 2009), relating the $\mathrm{N}_{2} / \mathrm{CO}_{2}$ ratio of volcanic gases to that of homogenized melt inclusions is not straightforward. Additional results from in situ $\mathrm{N}$ measurements of MIs, analyses of gases discharging from volcanoes and hydrothermal systems, and high $P$ and $T$ experiments will be key for improving our understanding of the behavior and fate of $\mathrm{N}$ at convergent plate margins.

\section{3. $\mathrm{N}$ and $\mathrm{CO}_{2}$ contents of primary Klyuchevskoy melts}

Quantifying the $\mathrm{N}$ and $\mathrm{CO}_{2}$ contents of undegassed mantle-derived melts is challenging because the low solubility of these volatiles in silicate melts (Section 4.2) results in extensive volatile loss from almost all magmas, and, possibly, degassing-induced $\mathrm{N} / \mathrm{CO}_{2}$ fractionation in the crust or shallow 
mantle. In addition, atmospheric (and crustal) contamination can modify the volatile characteristics of magmas en route to the surface (e.g., Cartigny et al., 2001).

Whereas SIMS analyses of MIs provide reliable constraints on the $\mathrm{CO}_{2}$ contents of MORB magmas and their mantle source (i.e., $\mathrm{CO}_{2, \mathrm{DMM}}=137 \pm 54 \mathrm{ppm}$; Le Voyer et al., 2017), $\mathrm{N}$ concentration estimates have so far relied on analyses of vesicles and glass by crushing and melting, respectively, of vesicular submarine basaltic glasses (e.g., Marty, 1995). Marty and Zimmermann (1999) measured the $\mathrm{N}$ concentrations in MORB glasses from different locations around the globe by static mass spectrometry and obtained values of $\leq 0.15$ ppm N (Figure 3). Fischer and Marty (2005) then derived the $\mathrm{N}-\mathrm{CO}_{2}$ characteristics of primary undegassed MORB melts from the $\mathrm{N}_{2} /{ }^{3} \mathrm{He}$ and $\mathrm{CO}_{2} /{ }^{3} \mathrm{He}$ ratios of these MORB glasses, and by estimating the ${ }^{3} \mathrm{He}$ content of the upper mantle $(1.79 \times$ $10^{-15} \mathrm{~mol} / \mathrm{g}$ ) and the degree of partial melting (10\%); thus, MORB melts are inferred to initially contain $\sim 0.04$ to $1.7 \mathrm{ppm} \mathrm{N}$ (Figure 3). Assuming a partial melting degree of $\sim 10 \%$ and strong partitioning of $\mathrm{N}$ into the melt, this concentration range implies that the MORB mantle contains $<0.17$ ppm $\mathrm{N}$, which is roughly comparable with more recent estimates of the $\mathrm{N}$ content of the MORB mantle, i.e., $0.09 \pm 0.05$ to $0.27 \pm 0.16 \mathrm{ppm}$ (Marty, 2012, and references therein) or 0.21-0.69 ppm (Bekaert et al., 2021). It is noteworthy that Johnson and Goldblatt (2015) argued for a higher N abundance of $1.2 \pm 0.8 \mathrm{ppm}$ in the MORB source based on a compilation of literature data for various terrestrial samples. This higher value appears consistent with that of Javoy and Pineau (1991) ( 1 $\mathrm{ppm}$ ), derived from the $\mathrm{N}$ content ( $\sim 12 \mathrm{ppm}$ ) of the famous "popping" rock $2 \pi \mathrm{D} 43$ (ABP0002-043VG8482 in PetDB), which has been interpreted to be the best preserved sample of undegassed melt derived from the upper mantle (e.g., Cartigny et al., 2008; Javoy and Pineau, 1991; Moreira et al., 1998; Sarda and Graham, 1990). However, $2 \pi D 43$ is an E-MORB (i.e., with a high $\mathrm{La} / \mathrm{Sm}_{\mathrm{N}}$ ratio of 1.9; Le Voyer et al., 2014), and its high volatile content has been argued to be the result of bubble accumulation in a magma chamber (e.g., Chavrit et al., 2014; Moreira and Kurz, 2013; Jones et al., 2019). Although the $\mathrm{N}$ content of the MORB mantle is still debated, the MORB source appears to predominantly generate melts containing $<2 \mathrm{ppm} \mathrm{N}$ (Figure 3).

The $\mathrm{N}$ and $\mathrm{CO}_{2}$ abundances in sub-arc mantle melts are expected to be higher than in magmas derived from the MORB mantle, as a result of devolatilization of the subducting slab, and addition of $\mathrm{N}$ and $\mathrm{CO}_{2}$ from oceanic sediments and/or altered oceanic crust into the mantle wedge (Fischer and Marty, 2005). However, $\mathrm{CO}_{2}$ concentrations in the glass phase of most MIs from subduction-related settings are significantly lower $(\leq 500 \mathrm{ppm})$ than those predicted for primary arc magmas $(>3000 \mathrm{ppm}$; e.g., Wallace, 2005) because melts are partially degassed prior to trapping within minerals of relatively evolved composition and/or because most inclusions contain a fluid bubble, which can host a substantial fraction of the total $\mathrm{CO}_{2}$ initially dissolved in the melt (e.g., Mironov et al., 2015; Moore et al., 2015, 2018). Homogenized MIs from Klyuchevskoy volcano are, therefore, unique in that they contain up to $4844 \pm 823 \mathrm{ppm} \mathrm{CO}_{2}$ (this study; Mironov et al., 2015). These homogenized MIs also have exceptionally high $\mathrm{CO}_{2} / \mathrm{Nb}$ ratios of $\sim 3300$ to 5500 , significantly higher than the $\mathrm{CO}_{2} / \mathrm{Nb}$ ratio of 
the MORB mantle $\left(\mathrm{CO}_{2} / \mathrm{Nb}=505 \pm 168\right.$ to $810 \pm 220$; Cartigny et al., 2008; Hirschmann, 2018; Le Voyer et al., 2017, 2019; Rosenthal et al., 2015) and of popping rock $2 \pi \mathrm{D} 43\left(\mathrm{CO}_{2} / \mathrm{Nb}=556\right.$; Cartigny et al., 2008). These high $\mathrm{CO}_{2} / \mathrm{Nb}$ ratios imply that $>80 \%$ of the $\mathrm{CO}_{2}$ in primary Klyuchevskoy melts and their mantle source is derived from the subducting slab (Mironov et al., 2015). In addition, the $\mathrm{N} / \mathrm{Nb}$ ratio of completely homogenized inclusions - which is on the order of 20-25 (\#C10-2; supplementary Table A.1) - differs substantially from that of the MORB mantle $(\mathrm{N} / \mathrm{Nb} \approx 0.24-9.5$, assuming $\mathrm{N}=0.05-2$ ppm (Bekaert et al., 2021; Johnson and Goldblatt, 2015; Marty, 2012) and Nb = $0.21 \mathrm{ppm}$ (Salters and Stracke, 2004) for the MORB mantle) and popping rock ( $\mathrm{N} / \mathrm{Nb} \approx 0.5$; Cartigny et al., 2008; Javoy and Pineau, 1991). Using these N/Nb estimates, we calculate that 52 to $99 \%$ of $\mathrm{N}$ in the Klyuchevskoy melts may be derived from the subducting slab.

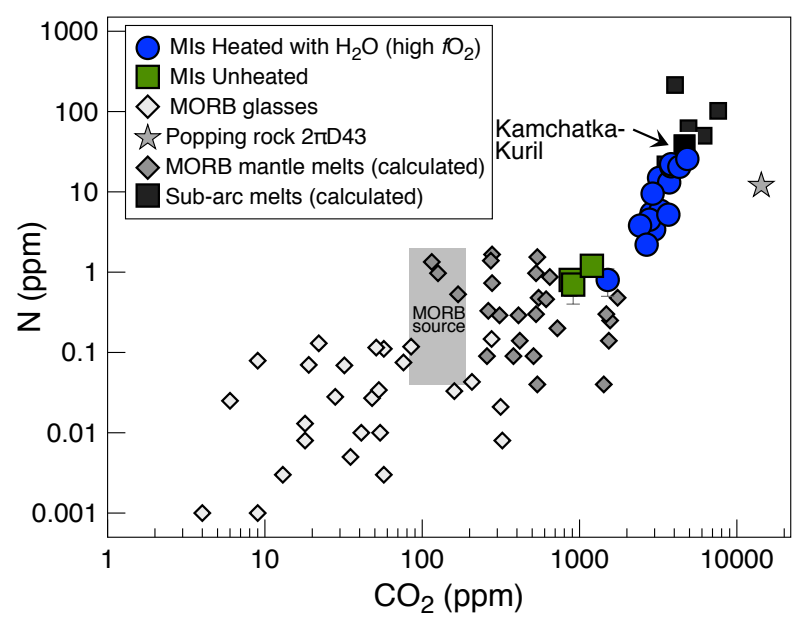

Figure 3: Measured $\mathrm{N}$ and $\mathrm{CO}_{2}$ contents of Klyuchevskoy melt inclusions (heated with $\mathrm{H}_{2} \mathrm{O}$ or unheated) from this study in comparison with measured $\mathrm{N}$ and $\mathrm{CO}_{2}$ concentrations in MORB glasses

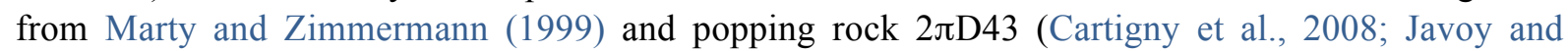
Pineau, 1991). Also shown are calculated $\mathrm{N}$ and $\mathrm{CO}_{2}$ abundances in undegassed MORB mantle melts and sub-arc melts from Fischer and Marty (2005). The $\mathrm{N}_{-}-\mathrm{CO}_{2}$ characteristics of undegassed MORB and sub-arc mantle melts were derived from the $\mathrm{N}_{2} /{ }^{3} \mathrm{He}$ and $\mathrm{CO}_{2} /{ }^{3} \mathrm{He}$ ratios of MORB glasses and volcanic or hydrothermal gas discharges, respectively, and by assuming a similar ${ }^{3} \mathrm{He}$ content of the crystalline mantle below mid-ocean ridges and volcanic arcs (see Fischer and Marty (2005) for details). The grey rectangle indicates the $\mathrm{CO}_{2}(137 \pm 54 \mathrm{ppm}$; Le Voyer et al., 2017) and $\mathrm{N}$ content $(0.09 \pm 0.05$ to $1.2 \pm 0.8$ ppm; Marty, 2012; Johnson and Goldblatt, 2015; Bekaert et al., 2021) of the MORB source.

Overall, the data from this study demonstrate that melts generated beneath Klyuchevskoy volcano have high absolute concentrations of $\mathrm{N}$ and $\mathrm{CO}_{2}$ compared to most melts generated at midocean ridges. In addition, Klyuchevskoy melts have highly elevated $\mathrm{N} / \mathrm{Nb}$ and $\mathrm{CO}_{2} / \mathrm{Nb}$ ratios compared to all MORB magmas and their mantle sources. These findings demonstrate that $\mathrm{N}$ is subducted (at least) to mantle depths relevant for magma genesis at the Kamchatka-Kuril arc. It is, however, noteworthy that Klyuchevskoy MIs, as well as the parent melt composition calculated for the Kuril-Kamchatka arc based on measured volatile fluxes (Fisher and Marty, 2005), plot at the lower 
end of the estimated $\mathrm{N}$ and $\mathrm{CO}_{2}$ concentrations for arc melts globally in Figure 3. The relatively low $\mathrm{N}$ and $\mathrm{CO}_{2}$ concentrations are consistent with a low influx of biogenic sediments at this convergent margin (Aiuppa et al., 2019; Plank and Langmuir, 1998). This implies that the $\mathrm{N}$ abundance in (homogenized) olivine-hosted MIs from other convergent margins, with a higher influx of organic N(C)-bearing sediments, may significantly exceed that of Klyuchevskoy MIs.

\section{Conclusions}

SIMS is a powerful technique for probing the $\mathrm{N}$ content of the glass phase of individual MIs in mantle-derived samples. However, given the low $\mathrm{N}$ abundance in Earth's mantle, application of this method requires the availability of $\mathrm{N}$-poor, homogeneous reference glasses. Moreover, MIs also commonly contain fluid bubbles that formed during cooling and decompression, and such bubbles may host a substantial portion of $\mathrm{N}$ that was initially dissolved in the melt. This post-entrapment modification process must be accounted for or reversed when determining the pre-degassed $\mathrm{N}$ budget based on analyses of MI glasses. Experimental homogenization and re-hydration of olivine-hosted MIs from a high-MgO lava flow of Klyuchevskoy volcano, coupled with a new high-resolution SIMS method, allowed us, for the first time, to determine the pre-eruptive concentration of $\mathrm{N}$ in an arc magma. The results demonstrate that primary Klyuchevskoy melts have high $\mathrm{N}$ concentrations as well as high $\mathrm{N} / \mathrm{Nb}$ (and $\mathrm{CO}_{2} / \mathrm{Nb}$ ) ratios compared to MORB mantle melts, thus indicating that a significant amount of $\mathrm{N}$ is subducted (at least) to sub-arc mantle depths beneath Kamchatka and recycled back to the crust and atmosphere by subduction-related magmatism. It is noteworthy that the MIs studied here were entrapped at high pressure in primitive olivine $(\mathrm{Fo}>85)$. Since more commonly studied arc melts may be partially degassed prior to entrapment within more evolved minerals, such MIs may record lower $\mathrm{N}$ (and $\mathrm{CO}_{2}$ ) abundances - unless the influx of organic $\mathrm{N}(-\mathrm{C})$-bearing sediments significantly exceeds that of the Kamchatka-Kuril arc. Therefore, additional in situ $\mathrm{N}$ measurements of primitive MIs in other arc-related magmas, together with analyses of gases discharging from volcanoes and hydrothermal systems and high $P$ and $T$ experiments, are crucially needed for completing our understanding of the behavior and fate of $\mathrm{N}$ at subduction zones.

\section{Declaration of interests}

The authors declare that they have no known competing financial interests or personal relationships that could have appeared to influence the work reported in this paper.

\section{Acknowledgements}

We thank Nordine Bouden for his help during the SIMS analyses. Comments from Long Li, Pierre Cartigny, and Tobias Fischer helped to improve the manuscript. EF and CD were supported by the European Research Council (ERC) under the European Union's Horizon 2020 research and innovation program (grant agreement no. 715028). MP, NM, and RB acknowledge support from the joint DFG- 
RFBR project BO2941/6-1 (DFG) and 20-55-12013 (RFBR), as well as HO1337/44-1 (DFG). This is

CRPG contribution 2787.

\section{Appendix A. Supplementary material}

\section{References}

Aiuppa, A., Fischer, T.P., Plank, T., Bani, P., 2019. $\mathrm{CO}_{2}$ flux emissions from the Earth's most actively degassing volcanoes, 2005-2015. Sci. Rep. 9, 5442. doi:10.1038/s41598-019-41901-y

Ariskin, A.A., Barmina, G.S., Ozerov, A.Y., Nielsen, R.L., 1995. Genesis of high-alumina basalts from Klyuchevskoi volcano. Petrology 5, 449-472 [Translated from Petrogiya 3, 496-521]

Barry, P.H., Hilton, D.R., 2016. Release of subducted sedimentary nitrogen throughout Earth's mantle. Geochemical Perspect. Lett. 2, 148-159. doi:10.7185/geochemlet.1615

Bebout, G.E., Fogel, M.L., 1992. Nitrogen-isotope compositions of metasedimentary rocks in the Catalina Schist, California: Implications for metamorphic devolatilization history. Geochim. Cosmochim. Acta 56, 2839-2849. doi:10.1016/0016-7037(92)90363-N

Bebout, G.E., Lazzeri, K.E., Geiger, C.A., 2016. Pathways for nitrogen cycling in Earth's crust and upper mantle: A review and new results for microporous beryl and cordierite. Am. Mineral. 101, 7-24. doi:10.2138/am-2016-5363

Bekaert, D. V, Turner, S.J., Broadley, M.W., Barnes, J.D., Halldórsson, S.A., Labidi, J., Wade, J., Walowski, K.J., Barry, P.H., 2021. Subduction-Driven Volatile Recycling: A Global Mass Balance. Annu. Rev. Earth Planet. Sci. 49, 37-70. doi:10.1146/annurev-earth-071620-055024

Bergal-Kuvikas, O., Nakagawa, M., Kuritani, T., Muravyev, Y., Malik, N., Klimenko, E., Amma-Miyasaka, M., Matsumoto, A., Shimada, S., 2017. A petrological and geochemical study on time-series samples from Klyuchevskoy volcano, Kamchatka arc. Contrib. to Mineral. Petrol. 172, 35. doi:10.1007/s00410-017$1347-\mathrm{z}$

Bernadou, F., Gaillard, F., Füri, E., Marrocchi, Y., Slodczyk, A. 2021. Nitrogen solubility in basaltic silicate melt - Implications for degassing processes. Chem. Geol., 573, 120192. doi:10.1016/j.chemgeo.2021.120192

Boulliung, J., Füri, E., Dalou, C., Tissandier, L., Zimmermann, L., Marrocchi, Y., 2020. Oxygen fugacity and melt composition controls on nitrogen solubility in silicate melts. Geochim. Cosmochim. Acta 284, 120133. doi:10.1016/j.gca.2020.06.020

Burnard, P., 2001. Correction for volatile fractionation in ascending magmas: Noble gas abundances in primary mantle melts. Geochim. Cosmochim. Acta 65, 2605-2614. doi:10.1016/S0016-7037(01)00605-6

Busigny, V., Cartigny, P., Laverne, C., Teagle, D., Bonifacie, M., Agrinier, P., 2019. A re-assessment of the nitrogen geochemical behavior in upper oceanic crust from Hole 504B: Implications for subduction budget in Central America. Earth Planet. Sci. Lett. 525, 115735. doi:10.1016/j.epsl.2019.115735

Busigny, V., Cartigny, P., Philippot, P., 2011. Nitrogen isotopes in ophiolitic metagabbros: A re-evaluation of modern nitrogen fluxes in subduction zones and implication for the early Earth atmosphere. Geochim. Cosmochim. Acta 75, 7502-7521. doi:10.1016/j.gca.2011.09.049

Busigny, V., Cartigny, P., Philippot, P., Ader, M., Javoy, M., 2003. Massive recycling of nitrogen and other fluid-mobile elements $(\mathrm{K}, \mathrm{Rb}, \mathrm{Cs}, \mathrm{H})$ in a cold slab environment: evidence from HP to UHP oceanic metasediments of the Schistes Lustrés nappe (western Alps, Europe). Earth Planet. Sci. Lett. 215, 27-32. doi:10.1016/S0012-821X(03)00453-9

Cartigny, P., Jendrzejewski, N., Pineau, F., Petit, E., Javoy, M., 2001. Volatile (C, N, Ar ) variability in MORB and the respective roles of mantle source heterogeneity and degassing: the case of the Southwest Indian Ridge. Earth Planet. Sci. Lett. 194, 241-257. doi:10.1016/S0012-821X(01)00540-4

Cartigny, P., Pineau, F., Aubaud, C., Javoy, M., 2008. Towards a consistent mantle carbon flux estimate: Insights from volatile systematics $\left(\mathrm{H}_{2} \mathrm{O} / \mathrm{Ce}, \delta \mathrm{D}, \mathrm{CO}_{2} / \mathrm{Nb}\right)$ in the North Atlantic mantle $\left(14{ }^{\circ} \mathrm{N}\right.$ and $\left.34{ }^{\circ} \mathrm{N}\right)$. Earth Planet. Sci. Lett. 265, 672-685. doi: 10.1016/j.epsl.2007.11.011

Chavrit, D., Humler, E., Grasset, O., 2014. Mapping modern $\mathrm{CO}_{2}$ fluxes and mantle carbon content all along the mid-ocean ridge system. Earth Planet. Sci. Lett. 387, 229-239. doi:10.1016/j.eps1.2013.11.036

Clor, L.E., Fischer, T.P., Hilton, D.R., Sharp, Z.D., Hartono, U., 2005. Volatile and N isotope chemistry of the Molucca Sea collision zone: Tracing source components along the Sangihe Arc, Indonesia. Geochem. Geophy. Geosy. 6, Q03J14. doi:10.1029/2004GC000825

Dalou, C., Hirschmann, M.M., Jacobsen, S.D., Le Losq, C., 2019a. Raman spectroscopy study of C-O-H-N speciation in reduced basaltic glasses: Implications for reduced planetary mantles. Geochim. Cosmochim. Acta 265, 32-47. doi:10.1016/j.gca.2019.08.029

Dalou C., Füri, E., Deligny, C., Piani, L., Caumon, M.-C., Laumonier, M., Boulliung, J. and Eden, M., 2019b. 
Redox control on nitrogen isotope fractionation during planetary core formation. PNAS 116(29), 1448514495. doi:10.1073/pnas.1820719116

Danyushevsky, L.V., McNeill, A.W., Sobolev, A.V., 2002. Experimental and petrological studies of melt inclusions in phenocrysts from mantle-derived magmas: an overview of techniques, advantages and complications. Chem. Geol., 183, 5-24. doi:10.1016/S0009-2541(01)00369-2

Dixon, J.E., 1997. Degassing of alkalic basalts. Am. Mineral. 82, 368-378. doi:10.2138/am-1997-3-415

Dixon, J.E., Stolper, E.M., Holloway, J.R., 1995. An Experimental Study of Water and Carbon Dioxide Solubilities in Mid-Ocean Ridge Basaltic Liquids. Part I : Calibration and Solubility Models. J. Petrol. 36, 1607-1631. doi:10.1093/oxfordjournals.petrology.a037267

Dorendorf, F., Wiechert, U., Wörner, G., 2000. Hydrated sub-arc mantle: a source for the Kluchevskoy volcano, Kamchatka/ Russia. Earth Planet. Sci. Lett. 175, 69-86. doi:10.1016/S0012-821X(99)00288-5

Elkins, L.J., Fischer, T.P., Hilton, D.R., Sharp, Z.D., McKnight, S., Walker, J., 2006. Tracing nitrogen in volcanic and geothermal volatiles from the Nicaraguan volcanic front. Geochim. Cosmochim. Acta 70, 5215-5235. doi:10.1016/j.gca.2006.07.024

Fedotov, S.A., Zharinov, N.A., Gontovaya, L.I., 2010. The magmatic system of the Klyuchevskaya group of volcanoes inferred from data on its eruptions, earthquakes, deformation, and deep Structure. J. Volcanol. Seismol. 4, 1-33. doi:10.1134/S074204631001001X

Fischer, T.P., Hilton, D.R., Zimmer, M.M., Shaw, A.M., Sharp, Z.D., Walker, J.A., 2002. Subduction and Recycling of Nitrogen Along the Central American Margin. Science 297, 1154-1157. doi:10.1126/science.1073995

Fischer, T.P., Marty, B., 2005. Volatile abundances in the sub-arc mantle: insights from volcanic and hydrothermal gas discharges. J. Volcanol. Geotherm. Res. 140, 205-216. doi:10.1016/j.jvolgeores.2004.07.022

Fischer, T.P., Ramírez, C., Mora-Amador, R.A., Hilton, D.R., Barnes, J.D., Sharp, Z.D., Le Brun, M., de Moor, J.M., Barry, P.H., Füri, E., Shaw, A.M., 2015. Temporal variations in fumarole gas chemistry at Poás volcano, Costa Rica. J. Volcanol. Geotherm. Res. 294. doi:10.1016/j.jvolgeores.2015.02.002

Fischer, T.P., Takahata, N., Sano, Y., Sumino, H., Hilton, D.R., 2005. Nitrogen isotopes of the mantle: Insights from mineral separates. Geophys. Res. Lett. 32, 1-5. doi:10.1029/2005GL022792

Fogel, R.A., 1994. Nitrogen solubility in aubrite and E chondrite melts. Lunar and Planetary Science Conference, vol. 25, 383-384.

Füri, E., Deloule, E., Dalou, C., 2018. Nitrogen abundance and isotope analysis of silicate glasses by secondary ionization mass spectrometry. Chem. Geol. 493, 327-337. doi:10.1016/j.chemgeo.2018.06.008

Gaillard, F., Bouhifd, M.A., Füri, E., Malavergne, V., Marrocchi, Y., Noack, L., Ortenzi, G., Roskosz, M., Vulpius, S., 2021. The diverse planetary ingassing/outgassing paths produced over billions of years of magmatic activity. Space Sci. Rev., 217, 22, doi: 10.1007/s11214-021-00802-1

Grewal, D.S., Dasgupta, R., Farnell, A., 2020. The speciation of carbon, nitrogen, and water in magma oceans and its effect on volatile partitioning between major reservoirs of the Solar System rocky bodies. Geochim. Cosmochim. Acta 280, 281-301. doi:10.1016/j.gca.2020.04.023

Grewal, D.S., Dasgupta, R., Holmes, A.K., Costin, G., Li, Y., Tsuno, K., 2019. The fate of nitrogen during coremantle separation on Earth. Geochim. Cosmochim. Acta 251, 87-115. doi:10.1016/j.gca.2019.02.009

Halama, R., Bebout, G.E., John, T., Scambelluri, M., 2012. Nitrogen recycling in subducted mantle rocks and implications for the global nitrogen cycle. Int. J. Earth Sci. 103, 2081-2099. doi:10.1007/s00531-0120782-3

Halama, R., Bebout, G.E., John, T., Schenk, V., 2010. Nitrogen recycling in subducted oceanic lithosphere: The record in high- and ultrahigh-pressure metabasaltic rocks. Geochim. Cosmochim. Acta 74, 1636-1652. doi:10.1016/j.gca.2009.12.003

Halldórsson, S.A., Hilton, D.R., Troll, V.R., Fischer, T.P., 2013. Resolving volatile sources along the western Sunda arc, Indonesia. Chem. Geol. 339, 263-282. doi:10.1016/j.chemgeo.2012.09.042

Hilton, D.R., Fischer, T.P., Marty, B., 2002. Noble gases and volatile recycling at subduction zones. In Noble Gases in Geochemistry and Cosmochemistry, vol. 47 (eds. D. Porcelli, C. Ballentine and R. Wieler), pp. 319-370. Rev. Mineral. Geochem. Mineral. Soc. Am., Washington, DC.

Hirschmann, M.M., 2018. Comparative deep Earth volatile cycles: The case for $\mathrm{C}$ recycling from exosphere/ mantle fractionation of major $\left(\mathrm{H}_{2} \mathrm{O}, \mathrm{C}, \mathrm{N}\right)$ volatiles and from $\mathrm{H}_{2} \mathrm{O} / \mathrm{Ce}, \mathrm{CO}_{2} / \mathrm{Ba}$, and $\mathrm{CO}_{2} / \mathrm{Nb}$ exosphere ratios 502, 262-273. doi:10.1016/j.eps1.2018.08.023

Humbert, F., 1998. Solubilité de l'azote dans les silicates liquides - Influence de la fugacité d'oxygène et de la composition. Ph.D thesis, Université Henri Poincaré, Nancy.

Jackson, C.R.M., Cottrell, E., Andrews, B., 2021. Warm and oxidizing slabs limit ingassing efficiency of nitrogen to the mantle. Earth Planet. Sci. Lett. 553, 116615. doi:10.1016/j.eps1.2020.116615

Javoy, M., Pineau, F., 1991. The volatiles record of a "popping" rock from the Mid-Atlantic Ridge at $14^{\circ} \mathrm{N}$ : chemical and isotopic composition of gas trapped in the vesicles. Earth Planet. Sci. Lett. 107, 598-611. 
doi:10.1016/0012-821X(91)90104-P

Jiang, G., Zhao, D., Zhang, G., 2009. Seismic tomography of the Pacific slab edge under Kamchatka. Tectonophysics 465, 190-203. doi:10.1016/j.tecto.2008.11.019

Johnson, B., Goldblatt, C., 2015. The nitrogen budget of Earth. Earth-Science Rev. 148, 150-173. doi:10.1016/j.earscirev.2015.05.006

Jones, M.R., Wanless, V.D., Soule, S.A., Kurz, M.D., Mittelstaedt, E., Fornari, D.J., Curtice, J., Klein, F., Le Roux, V., Brodsky, H., Péron, S., Schwartz, D.M., 2019. New constraints on mantle carbon from MidAtlantic Ridge popping rocks. Earth Planet. Sci. Lett. 511, 67-75. doi:10.1016/j.eps1.2019.01.019

Kadik, A.A., Koltashev, V.V., Kryukova, E.B., V.G., P., Tsekhonya, T.I., Kononkova, N.N., 2015. Solubility of nitrogen, carbon, and hydrogen in $\mathrm{FeO}-\mathrm{Na}_{2} \mathrm{O}-\mathrm{Al}_{2} \mathrm{O}_{3}-\mathrm{SiO}_{2}$ melt and liquid iron alloy: influence of oxygen fugacity. Geochemistry Int. 53, 849-868. doi:10.1134/S001670291510002X

Kadik, A.A., Kurovskaya, N.A., Ignat, Y.A., Kononkova, N.N., 2011. Influence of oxygen fugacity on the solubility of nitrogen, carbon, and hydrogen in $\mathrm{FeO}-\mathrm{Na}_{2} \mathrm{O}-\mathrm{SiO}_{2}-\mathrm{Al}_{2} \mathrm{O}_{3}$ melts in equilibrium with metallic iron at $1.5 \mathrm{GPa}$ and $1400^{\circ} \mathrm{C}$. Geochemistry Int. 49, 429-438. doi:10.1134/S001670291105003X

Kersting, A.B., Arculus, R.J., 1994. Klyuchevskoy Volcano, Kamchatka, Russia: The Role of High-Flux Recharged, Tapped, and Fractionated Magma Chamber(s) in the Genesis of High- $\mathrm{Al}_{2} \mathrm{O}_{3}$ from High-MgO Basalt. J. Petrol. 35, 1-41. doi:10.1093/petrology/35.1.1

Khubunaya, S.A., Bogoyavlenskii S.O., Novgorodtseva T.Y. Okrugina A.I., 1993. Mineralogical features of magnesian basalts as a reflection of fractionation in the magmatic chamber of Klyuchevskoi volcano. Vulkanol. Seismol. 3, 46-68.

Koulakov, I., Abkadyrov, I., Al Arifi, N., Deev, E., Droznina, S., Gordeev, E.I., Kakovlev, A., El Khrepy, S., Kulakov, R.I., Kugaenko, Y., Novgorodova, A., Senyukov, S., Shapiro, N., Stupina, T., West, M., 2017. Three different types of plumbing system beneath the neighboring active volcanoes of Tolbachik, Bezymianny, and Klyuchevskoy in Kamchatka. J. Geophys. Res. Solid Earth 122, 3852-3874. doi:10.1002/2017JB014082

Levin, V., Shapiro, N., Park, J., Ritzwoller, M., 2002. Seismic evidence for catastrophic slab loss beneath Kamchatka. Nature 418, 763-767. doi:10.1038/nature00973

Le Voyer, M., Cottrell, E., Kelley, K.A., Brounce, M., Hauri, E.H., 2014. The effect of primary versus secondary processes on the volatile content of MORB glasses: An example from the equatorial Mid-Atlantic Ridge $\left(5^{\circ} \mathrm{N}-3^{\circ} \mathrm{S}\right)$. J. Geophys. Res. 120, 125-144. doi:10.1002/2014JB011160

Le Voyer, M., Kelley, K.A., Cottrell, E., Hauri, E.H., 2017. Heterogeneity in mantle carbon content from $\mathrm{CO}_{2}$ undersaturated basalts. Nat. Commun. 8, 14062. doi:10.1038/ncomms 14062

Le Voyer, M., Hauri, E.H., Cottrell, E., Kelley, K.A., Salters, V.J.M., Langmuir, C.H., Hilton, D.R., Barry, P.H., Füri, E., 2019. Carbon fluxes and primary magma $\mathrm{CO}_{2}$ contents along the global mid-ocean ridge system. Geochem. Geophy. Geosy. 20, 1387-1424. doi:10.1029/2018GC007630

Lee, H., Fischer, T.P., Maarten de Moor, J., Sharp, Z.D., Takahata, N., Sano, Y., 2017. Nitrogen recycling at the Costa Rican subduction zone: The role of incoming plate structure. Sci. Rep. 7, 139330. doi:10.1038/s41598-017-14287-y

Li, L., Bebout, G.E., 2005. Carbon and nitrogen geochemistry of sediments in the Central American convergent margin: Insights regarding subduction input fluxes, diagenesis, and paleoproductivity. J. Geophys. Res. 110, B11202. doi:10.1029/2004JB003276

Li, L., Bebout, G.E., Idleman, B.D., 2007. Nitrogen concentration and $\delta^{15} \mathrm{~N}$ of altered oceanic crust obtained on ODP Legs 129 and 185: Insights into alteration-related nitrogen enrichment and the nitrogen subduction budget. Geochim. Cosmochim. Acta 71, 2344-2360. doi:10.1016/j.gca.2007.02.001

Li, L., Cartigny, P., Ader, M., 2009: Kinetic nitrogen isotope fractionation associated with thermal decomposition of $\mathrm{NH}_{3}$ : Experimental results and potential applications to trace the origin of $\mathrm{N}_{2}$ in natural gas and hydrothermal systems. Geochim. Cosmochim. Acta 73, 6282-6297. doi: 10.1016/j.gca.2009.07.016

Li, Y., Huang, R., Wiedenbeck, M., Keppler, H., 2015. Nitrogen distribution between aqueous fluids and silicate melts. Earth Planet. Sci. Lett. 411, 218-228. doi:10.1016/j.epsl.2014.11.050

Li, Y., Keppler, H., 2014. Nitrogen speciation in mantle and crustal fluids. Geochim. Cosmochim. Acta 129, 1332. doi:10.1016/j.gca.2013.12.031

Libourel, G., Marty, B., Humbert, F., 2003. Nitrogen solubility in basaltic melt. Part I. Effect of oxygen fugacity. Geochim. Cosmochim. Acta 67, 4123-4135. doi:10.1016/S0016-7037(03)00259-X

Mallik, A., Li, Y., Wiedenbeck, M., 2018. Nitrogen evolution within the Earth's atmosphere-mantle system assessed by recycling in subduction zones. Earth Planet. Sci. Lett. 482, 556-566. doi:10.1016/j.epsl.2017.11.045

Marty, B., 2012. The origins and concentrations of water, carbon, nitrogen and noble gases on Earth. Earth Planet. Sci. Lett. 313-314, 56-66. doi:10.1016/j.eps1.2011.10.040

Marty, B., 1995. Nitrogen content of the mantle inferred from $\mathrm{N}_{2}-$ Ar correlation in oceanic basalts. Nature 377 , 
326-329.

Marty, B., Almayrac, M., Barry, P.H., Bekaert, D. V, Broadley, M.W., Byrne, D.J., Ballentine, C.J., Caracausi, A., 2020. An evaluation of the $\mathrm{C} / \mathrm{N}$ ratio of the mantle from natural $\mathrm{CO}_{2}$-rich gas analysis: Geochemical and cosmochemical implications. Earth Planet. Sci. Lett. 551, 116574. doi:10.1016/j.eps1.2020.116574

Marty, B., Zimmermann, L., 1999. Volatiles (He, C, N, Ar) in mid-ocean ridge basalts: assesment of shallowlevel fractionation and characterization of source composition. Geochim. Cosmochim. Acta 63, 36193633. doi:10.1016/S0016-7037(99)00169-6

Mikhail, S., Barry, P.H., Sverjensky, D.A., 2017. The relationship between mantle pH and the deep nitrogen cycle. Geochim. Cosmochim. Acta 209, 149-160. doi:10.1016/j.gca.2017.04.007

Mikhail, S., Sverjensky, D.A., 2015. Nitrogen speciation in upper mantle fluids and the origin of Earth's nitrogen-rich atmosphere. Nat. Geosci. 7, 816-819. doi:10.1038/NGEO2271

Mironov, N.L., Portnyagin, M. V, 2011. $\mathrm{H}_{2} \mathrm{O}$ and $\mathrm{CO}_{2}$ in parental magmas of Kliuchevskoi volcano inferred from study of melt and fluid inclusions in olivine. Russ. Geol. Geophys. 52, 1353-1367. doi:10.1016/j.rgg.2011.10.007

Mironov, N., Portnyagin, M., Botcharnikov, R., Gurenko, A., Hoernle, K., Holtz, F., 2015. Quantification of the $\mathrm{CO}_{2}$ budget and $\mathrm{H}_{2} \mathrm{O}-\mathrm{CO}_{2}$ systematics in subduction-zone magmas through the experimental hydration of melt inclusions in olivine at high $\mathrm{H}_{2} \mathrm{O}$ pressure. Earth Planet. Sci. Lett. 425, 1-11. doi:10.1016/j.eps1.2015.05.043

Mironov, N.L., Tobelko, D.P., Smirnov, S.Z., Portnyagin M.V., Krasheninnikov, S.P., 2020. Estimation of $\mathrm{CO}_{2}$ content in the gas phase of melt inclusions using Raman spectroscopy: case study of inclusions in olivine from the Karymsky volcano (Kamchatka). Russ. Geol. Geophys. 61, 600-610. doi: 10.15372/RGG2019169.

Mitchell, E.C., Fischer, T.P., Hilton, D.R., Hauri, E.H., Shaw, A.M., de Moor, J.M., Sharp, Z.D., Kazahaya, K., 2010. Nitrogen sources and recycling at subduction zones: Insights from the Izu-Bonin-Mariana arc. Geochem. Geophy. Geosy. 11. doi:10.1029/2009GC002783

Miyazaki, A., Hiyagon, H., Sugiura, N., Hirose, K., Takahashi, E., 2004. Solubilities of nitrogen and noble gases in silicate melts under various oxygen fugacities: Implications for the origin and degassing history of nitrogen and noble gases in the Earth. Geochim. Cosmochim. Acta 68, 387-401. doi:10.1016/S00167037(03)00484-8

Moore, L.R., Gazel, E., Tuohy, R., Lloyd, A.S., Esposito, R., Steele-MacInnis, M., Hauri, E.H., Wallace, P.J., Plank, T., Bodnar, R.J., 2015. Bubbles matter: An assessment of the contribution of vapor bubbles to melt inclusion volatile budgets. Am. Mineral. 100, 806-823.

Moore, L.R., Mironov, N., Portnyagin, M., Gazel, E., Bodnar, R.J., 2018. Volatile contents of primitive bubblebearing melt inclusions from Klyuchevskoy volcano, Kamchatka: Comparison of volatile contents determined by mass-balance versus experimental homogenization. J. Volcanol. Geotherm. Res. 358, 124131. doi:10.1016/j.jvolgeores.2018.03.007

Moreira, M., Kurz, M.D., 2013. Noble gases as tracers of mantle processes and magmatic degassing. In The Noble Gases as Geochemical Tracers (ed. P. Burnard), pp. 371-391. Advances in Isotope Geochemistry, Springer, Berlin, Heidelberg. doi:10.1007/978-3-642-28836-4_12

Moreira, M., Kunz, J, Allègre, C., 1998. Rare gas systematics in popping rock: isotopic and elemental composition in the upper mantle. Science 279, 1178-1181. doi:10.1126/science.279.5354.1178

Mosenfelder, J.L., Von der Handt, A., Füri, E., Dalou, C., Hervig, R.L., Rossman, G.R., Hirschmann, M.M., 2019. Nitrogen incorporation in silicates and metals: Results from SIMS, EPMA, FTIR, and laserextraction mass spectrometry. Am. Mineral. 104, 31-46. doi:10.2138/am-2019-6533

Mulfinger, H.-O., 1966. Physical and Chemical Solubility of Nitrogen in Glass Melts. J. Am. Ceram. Soc. 49, 462-467. doi:10.1111/j.1151-2916.1966.tb13300.x

Mysen, B., 2019. Nitrogen in the Earth: abundance and transport. Prog. Earth Planet. Sci. Lett. 6, 38. doi:10.1186/s40645-019-0286-x

Mysen, B.O., Fogel, M.L., 2010. Nitrogen and hydrogen isotope compositions and solubility in silicate melts in equilibrium with reduced $(\mathrm{N}+\mathrm{H})$-bearing fluids at high pressure and temperature: Effects of melt structure. Am. Mineral. 95, 987-999. doi:10.2138/am.2010.3364

Mysen, B.O., Yamashita, S., Chertkova, N., 2008. Solubility and solution mechanisms of NOH volatiles in silicate melts at high pressure and temperature - Amine groups and hydrogen fugacity. Am. Mineral. 93, 1760-1770. doi:10.2138/am.2008.2879

Paonita, A., 2005. Noble gas solubility in silicate melts: a review of experimentation and theory, and implications regarding magma degassing processes. Ann. Geophys. 48, 647-669. doi:10.4401/ag-3225

Parkinson, I.J., Arculus, R.J., 1999. The redox state of subduction zones: insights from arc-peridotites. Chem. Geol. 160, 409-423. doi:10.1016/S0009-2541(99)00110-2

Plank, T., Langmuir, C.H., 1998. The chemical composition of subducting sediment and its consequences for the crust and mantle. Chem. Geol. 145, 325-394. doi:10.1016/S0009-2541(97)00150-2 
Portnyagin, M., Manea, V.C., 2008. Mantle temperature control on composition of arc magmas along the Central Kamchatka Depression. Geology 36, 519-522. doi: 10.1130/G24636A.1

Portnyagin, M., Ponomareva, V., 2012. Kliuchevskoi volcano diary. Int. J. Earth. Sci. (Geol. Rundsch.) 101, 195. doi.org/10.1007/s00531-011-0710-y

Portnyagin, M., Hoernle, K., Avdeiko, G., Hauff, F., Werner, R., Bindemann, I., Uspensky, V., GarbeSchönberg, D., 2005. Transition from arc to oceanic magmatism at the Kamchatka-Aleutian junction. Geology 33, 25-28. doi:10.1130/G20853.1

Portnyagin, M., Mironov, N., Botcharnikov, R., Gurenko, A., Almeev, R.R., Luft, C., Holtz, F., 2019. Dehydration of melt inclusions in olivine and implications for the origin of silica-undersaturated island-arc melts. Earth Planet. Sci. Lett. 517, 95-105. doi:10.1016/j.eps1.2019.04.021

Ray, M.C., Hilton, D.R., Muñoz, J., Fischer, T.P., Shaw, A.M., 2009. The effects of volatile recycling, degassing and crustal contamination on the helium and carbon geochemistry of hydrothermal fluids from the Southern Volcanic Zone of Chile 266, 38-49. doi:10.1016/j.chemgeo.2008.12.026

Regier, M.E., Hervig, R.L., Myers, M.L., Roggensack, K., Wilson, C.J.N., 2016. Analyzing nitrogen in natural and synthetic silicate glasses by secondary ion mass spectrometry. Chem. Geol. 447, $27-39$. doi:10.1016/j.chemgeo.2016.10.019

Roedder, E., 1979. Origin and significance of magmatic inclusions. Bull. Mineral. 102, 487-510.

Rosenthal, A., Hauri, E.H., Hirschmann, M.M., 2015. Experimental determination of C, F, and H partitioning between mantle minerals and carbonated basalt, $\mathrm{CO}_{2} / \mathrm{Ba}$ and $\mathrm{CO}_{2} / \mathrm{Nb}$ systematics of partial melting, and the $\mathrm{CO}_{2}$ contents of basaltic source regions. Earth Planet. Sci. Lett. 412, 77-87. doi:10.1016/j.epsl.2014.11.044

Roskosz, M., Bouhifd, M.A., Jephcoat, A.P., Marty, B., Mysen, B.O., 2013. Nitrogen solubility in molten metal and silicate at high pressure and temperature. Geochim. Cosmochim. Acta 121, 15-28. doi:10.1016/j.gca.2013.07.007

Roskosz, M., Mysen, B.O., Cody, G.D., 2006. Dual speciation of nitrogen in silicate melts at high pressure and temperature: An experimental study. Geochim. Cosmochim. Acta 70, 2902-2918. doi:10.1016/j.gca.2006.03.001

Salters, V.J.M., Stracke, A., 2004. Composition of the depleted mantle. Geochem. Geophy. Geosy. 5. doi: 10.1029/2003GC000597

Sano, Y., Takahata, N., Nishio, Y., Fischer, T.P., Williams, S.N., 2001. Volcanic flux of nitrogen from the Earth. Chem. Geol. 171, 263-271. doi:10.1016/S0009-2541(00)00252-7

Sano, Y., Takahata, N., Nishio, Y., Marty, B., 1998. Nitrogen recycling in subduction zones. Geophys. Res. Lett. 25, 2289-2292. doi:10.1029/98GL01687

Sarda, P., Graham, D., 1990. Mid-ocean ridge ppping rocks: Implications for degassing at ridge crests. Earth Planet. Sci. Lett. 97, 268-289. doi:10.1016/0012-821X(90)90047-2

Schiano, P., 2003. Primitive mantle magmas recorded as silicate melt inclusions in igneous minerals. EarthScience Rev. 63, 121-144. doi:10.1016/S0012-8252(03)00034-5

Shishkina, T.A., Botcharnikov, R.E., Holtz, F., Almeev, R.R., Portnyagin, M.V., 2010. Solubility of $\mathrm{H}_{2} \mathrm{O}$ and $\mathrm{CO}_{2}$-bearing fluids in tholeiitic basalts at pressures up to $500 \mathrm{MPa}$. Chem. Geol. 277, 115-125. doi: 10.1016/j.chemgeo.2010.07.014

Snyder, G., Poreda, R., Fehn, U., Hunt, A., 2003. Sources of nitrogen and methane in Central American geothermal settings: Noble gas and ${ }^{129} \mathrm{I}$ evidence for crustal and magmatic volatile components. Geochem. Geophy. Geosy. 4, 1-28. doi:10.1029/2002GC000363

Taran, Y.A., 2009. Geochemistry of volcanic and hydrothermal fluids and volatile budget of the KamchatkaKuril subduction zone. Geochim. Cosmochim. Acta 73, 1067-1094. doi:10.1016/j.gca.2008.11.020

Tingle, N.T., Green, H.W., Finnerty, A.A., 1988. Experiments and observations bearing on the solubility and diffusivity of carbon in olivine. J. Geophys. Res. 93, B12, 15289-15304. doi: 10.1029/JB093iB12p15289

Wallace, P.J., 2005. Volatiles in subduction zone magmas: concentrations and fluxes based on melt inclusion and volcanic gas data. J. Volcanol. Geotherm. Res. 140, 217-240. doi:10.1016/j.jvolgeores.2004.07.023

Watson, E.B., 2017. Diffusive fractionation of volatiles and their isotopes during bubble growth in magmas. Contrib. to Mineral. Petrol. 172, 61. doi:10.1007/s00410-017-1384-7

Watson, E.B., Cherniak, D.J., Drexler, M., Hervig, R.L., Schaller, M.F., 2019. Nitrogen diffusion in silicate minerals, with implications for nitrogen transport and cycling in the lithosphere. Chem. Geol. 516, 42-58. doi:10.1016/j.chemgeo.2019.04.006

Yogodzinski, G.M., Lees, J.M., Churikova, T.G., Dorendorf, F., Wöerner, G., Volynets, O.N., 2001. Geochemical evidence for the melting of subducting oceanic lithosphere at plate edges. Nature 409, 500504. doi:10.1038/35054039

Zerkle, A.L., Mikhail, S., 2017. The geobiological nitrogen cycle: From microbes to the mantle. Geobiology 15 , 343-352. doi:10.1111/gbi.12228

Zimmer, M.M., Fischer, T.P., Hilton, D.R., Alvarado, G.E., Sharp, Z.D., Walker, J.A., 2004. Nitrogen 
systematics and gas fluxes of subduction zones: Insights from Costa Rica arc volatiles. Geochem. Geophy. Geosy. 5. doi:10.1029/2003GC000651 